\title{
READING THE WRITING ON THE WALL: DISCOVERING NEW DIMENSIONS TO THE ANTONINE WALL DISTANCE SCULPTURES
}

\begin{abstract}
This paper explores new approaches to epigraphic evidence from the Antonine Wall that, in some respects, depart significantly from perceived wisdom. Addressing the inscriptions from alternative perspectives and incorporating attribute analysis, material mapping and a review of historical sources has revealed previously unexplored dimensions to a significant category of inscriptions here referred to as Distance Stones. The results cast new light onto these enigmatic ancient artefacts, exposing potential inconsistencies relating to units of measure and challenging hypotheses that have endured for more than two centuries. Critical review has uncovered patterns of difference and similarities that alter our perception of these unique frontier sculptures and lend credence to the proposal that they may have originally been placed, not along the Wall as has been traditionally accepted, but along the Military Way where passers-by could more meaningfully engage with them.
\end{abstract}

Keywords: Roman Epigraphy, Antonine Wall, Northern Britain, Frontiers, Material Culture.

\section{INTRODUCING THE ANTONINE WALL DISTANCE STONES}

$\mathbf{T}$ he Antonine Wall (Fig. 1) was commissioned around AD 142 by the Emperor Antoninus Pius to define Rome's north-west frontier ${ }^{1}$. The mural barrier is a turf rampart set on a stone base that stretches across central Scotland through the Forth-Clyde isthmus for 37 miles. It separated the Roman-controlled region to the south from the non-Roman north, although there were outpost and advance forts to the north of the Wall. Monumental inscriptions, traditionally referred to as distance slabs, were recovered from the environs of the Wall ${ }^{2}$ and many combine inscribed text and sculptural relief.

Carved from local sandstone, these monumental inscriptions are a rich textual and iconographic resource that provide a graphic account of the frontier ${ }^{3}$, commemorating and memorialising actions and reputations of the Emperor and dedicators in perpetuity ${ }^{4}$. The phrase 'distance slabs' was originally applied to this particular category of inscriptions ${ }^{5}$ because they record measurements of sections of the mural barrier constructed by three Roman Legions commemorated in the text (Legio II Augusta, Legio VI

\footnotetext{
HANSON/MAXWELL 1983; BREEZE 2015; ROBERTSON 2015

KEPPIE 1979; KEPPIE 1998.

3 FERRIS 2000, 111-13; BREEZE/FERRIS 2016.

WOOLF 1996, 26.

${ }^{5}$ BATES 1898.
}

\section{Louisa CAMPBELL}

LKAS Fellow in Archaeology, University of Glasgow, Louisa.Campbell@glasgow.ac.uk

DOI: $10.14795 /$ j.v7i2.513

ISSN 2360 - 266X

ISSN-L 2360 - 266X 


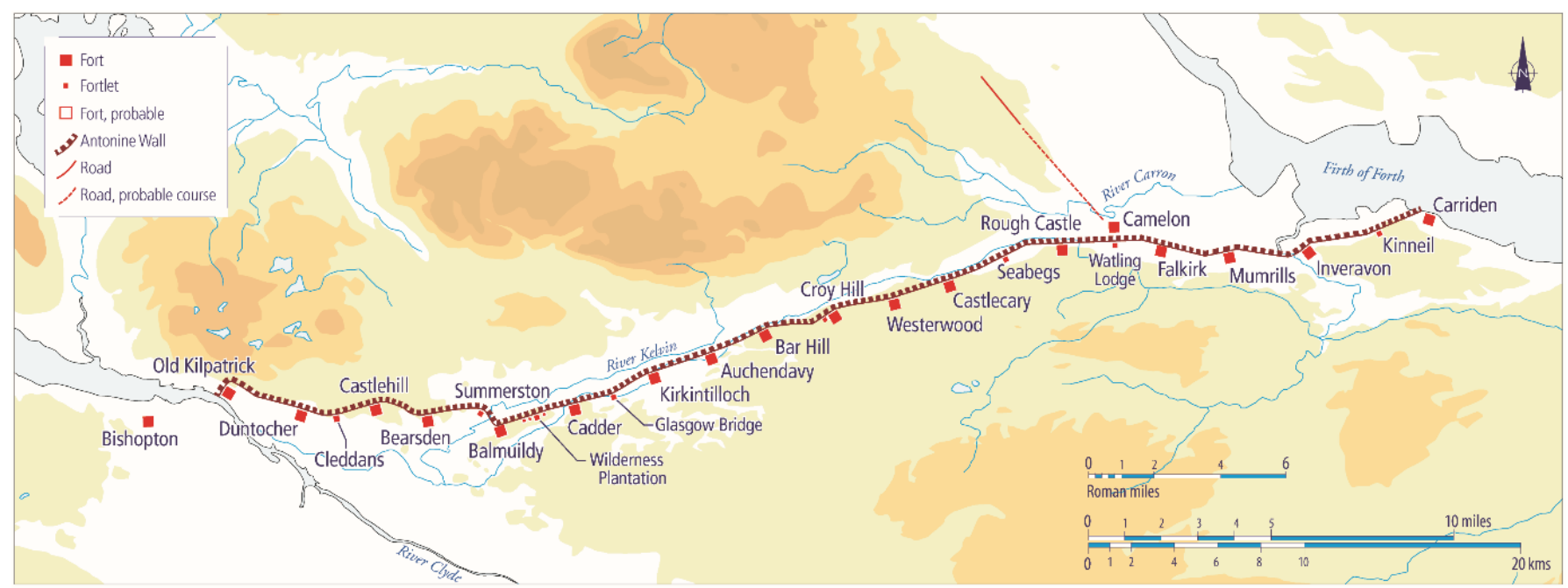

Fig. 1. Map of the Antonine Wall (๔ D J Breeze, reproduced with permission).

Victrix and Legio XX Valeria Victrix). They have also been referred to as 'Legionary tablets' and described as "so special a character as to demand separate treatment. Nothing exactly corresponding to it has been found anywhere else in the Roman world"6. It has been argued that traditional terminologies do not adequately reflect the cultural significance of these artefacts ${ }^{7}$ and they will instead be referred to here as Distance Stones, sculptures, monuments, monumental texts or inscriptions.

Building on the invaluable foundations laid down by Antiquarian scholars ${ }^{8}$, Sir George Macdonald ${ }^{9}$ produced a comprehensive survey of these sculptures of which 20 were then known. This number has increased only marginally in the intervening period with 21 currently recorded, two of which are now lost and one perished in a fire in Chicago, though a plaster cast of it survives. Of the remaining 19 known Distance Stones, 16 and the plaster cast are in the collections of the Hunterian Museum, University of Glasgow, one is in the Glasgow Museums store in Kelvin Hall and another is with the National Museum of Scotland, Edinburgh. More than a century on from Macdonald's declaration of their significance they remain the most impressive and impactful body of epigraphic evidence recovered from any Roman frontier ${ }^{10}$.

The monuments contain dedications to the Emperor, Antoninus Pius, who commissioned the construction of Rome's most north-westerly frontier under the governorship of Quintus Lollius Urbicus. The dedications are in stereotypically abbreviated Latin and incorporate variations of the Emperor's names, 'Caesar Titus Aelius Hadrianus Antoninus Augustus Pius'11. Relief sculpted decorative features and iconography on some depict legionary emblems, subjugation of indigenous peoples as well as religious practice and favoured deities. They promote Rome's domination over the region ${ }^{12}$ and the precision of recorded measurements appears to confirm the army's concern for

\footnotetext{
${ }^{6}$ MACDONALD 1911, 268.

CAMPBELL 2020

8 c.f. CAMDEN 1722; HORSLEY 1732; MAITLAND 1757; STUART 1852; CADEL 1871; BUCHANAN 1883; MACDONALD 1897.

${ }^{9}$ MACDONALD 1911; 1934

${ }^{10}$ FERRIS 2000, 110-3; BREEZE 2015, 69.

${ }^{11}$ KEPPIE 1979, 5 .

12 KEPPIE 1979, 4-5.
}

accuracy in ensuring that each Legion's contribution to construction of the frontier is properly commemorated along with their allegiance to the Emperor, a practice characteristic of honorific dedications on inscriptions of this period ${ }^{13}$.

It is the incorporation of measurements that sets this category of inscriptions apart from others and the reason for their nomenclature. The absence of the governor's name on any examples is notable $e^{14}$ and hinders our ability to pinpoint construction dates with precision. The inclusion of the Emperor's name on all but two does, however, provide a relatively tight chronology for this body of evidence since the frontier was occupied for only a brief period of c. 20 years. Most of the Distance Stones were donated to the University of Glasgow and Hunterian Museum by Antiquarians and landowners with other inscribed stones recovered by the Canal Commission during construction of the Forth and Clyde Canal ${ }^{15}$.

\section{DIVERGENT DISTANCES}

In reference to the Distance Stones, Macdonald ${ }^{16}$ notes a predecessor's "not unnatural reluctance to traverse the very explicit assertion of the Itinerarium, almost a canonical book in the eyes of eighteenth-century antiquaries". It is fair to say that Macdonald has himself become a canonical figure whose hypotheses continue to permeate scholarship relating to Roman Scotland in general and the Antonine Wall in particular. While recognising the tremendous contribution he and others have made to this field of study, this research suggests potential flaws in conventional interpretations relating to the Distance Stones that should be addressed. The intention here is not to minimise or invalidate these invaluable contributions, but rather it is to explore alternative interpretations and highlight some instances of selectivity in the use of historical sources as well as inconsistencies and incorrectly recorded findspots so that these can be set right for the record to ensure future researchers have accurate datasets to explore in the development of new interpretations.

\footnotetext{
${ }^{13}$ KOLB 2015, 658.

${ }^{14}$ HANSON/MAXWELL 1983, 113.

${ }^{15}$ MONUMENTA ROMANI IMPERII 1768; KEPPIE 2012, 93-96.

${ }^{16}$ MACDONALD1911, 292.
} 
Rather than attempt to deconstruct longstanding interpretations of units of measure inscribed onto the Distance Stones as distinguished by passus and pedes ${ }^{17}$, or reconstruct dimensions of built sectors of the mural barrier through complex computational challenges ${ }^{18}$, this work originally set out to undertake a contextual analysis and consider the potential placement of these unique monumental inscriptions and their subsequent impact on Roman and non-Roman audiences. In practice, toward that end we must first grasp the nettle on the contentious matter of measurements since it is not possible to extrapolate material meanings in the absence of firm foundations. A survey of historical accounts and modern maps has revealed unanticipated inconsistencies that have stood the test of time and imposed deep-rooted biases onto interpretations of the inscriptions and the associated frontier infrastructure.

Bates $^{19}$ first proposed the incorporation of $M P$ on all examples east of Castlehill (nos 1-8) refers to paces (Millia Passuum) and P P or $P$ on those to the west of Castlehill (nos 9-18) refers to feet (Pedes), (see Table 1 and Appendix I). This alteration, he suggested, explains their over-representation on the Wall's western sector since one roman pace equates to five feet, therefore those inscribed with $M P$ are thought to record longer distances constructed in the east. This explanation has persisted for more than a century, remaining current rationale for the proposed diverting of troops from constructing the Wall when it was near-complete at Castlehill to the task of building additional forts. They are thought thereafter to have returned in greater numbers to complete shorter sub-divided segments, explaining the more numerous examples recovered from the west and proposed pairings of some ${ }^{20}$.

This is a complex explanation to fit what is otherwise widely recognised as a partial material record ${ }^{21}$ into a reconstruction of the limes. It leaves little room for additional Distance Stones that undoubtedly remain undiscovered to slot into the sequence. Macdonald ${ }^{22}$ recognises this strategy could be misleading, but it serves as a means of "obtaining even a rough approximation". For example, in order to extrapolate the measurement recorded on Distance Stone no. 8 , one of a group of four inscriptions duplicating an oddly specific distance of $36661 / 2$ units of measures, he imposes the following actions:

1. Start from the corner of Castlehill fort, Bearsden;

2. Travel eastward for 18,028 English feet $=36661 / 2$ Roman paces;

3. Arrive 330 feet away from the Wall crossing the Balmore-Glasgow road passing Summerston Farm;

4. This spot is "some distance" beyond no. 7;

5. Extract "say" $2 \frac{1 / 2}{2}$ per cent to account for landscape undulations;

6. Retrace steps by "say" 450 feet;

7. This spot is 260 yards from the road and 600 yards from Summerston farm;

\footnotetext{
${ }_{17}$ HORSLEY 1732; MACDONALD 1934, 361.

${ }_{18}$ STRANG 2007; HANNON/ROHL/WILSON 2017.

19 BATES 1898, 107-109.

20 KEPPIE 1974, 151-2; KEPPIE 1979, 7; KEPPIE 1998. 52; HANSON/ MAXWELL 1983; HANNON/ROHL/WILSON 2017, 5.

${ }^{21}$ STUART 1852, 346; HANSON/MAXWELL 1983, 123; KEPPIE 1998, 52.

${ }^{22}$ MACDONALD 1934, 379.
}

8. According to Macdonald, "this will satisfy all the conditions" for no. 8 to mark the western end of a sector of the Wall recorded by nos 6 and 7 .

He takes this several steps further to establish the placement of no. 5 which he posits should be assigned 3666 $1 / 2$ paces east of nos 6 and 7 by the following actions:

1. Exclude the north rampart of Balmuildy fort (which he suggests were constructed by garrisons);

2. This spot is 494 feet short of the road between Bogton Farm and Easter Cawder;

3. Deduct "say" 215 feet from the dead-level total for undulations, "increasing the figure for the interval to 709";

4. This would be too far distant from Eastermains (the proposed location for no. 4) "to serve our purposes", so;

5. Extract the north rampart of Cadder fort and assume it was constructed by garrisons;

6. This will reduce the gap by 364 feet;

7. This provides a spot 345 feet west of the road and within easy reach of Cawder House (where no. 5 was installed).

His strategy is based upon rather elaborate speculation and estimations that do not measure the mural barrier with precision. While this attempt to see patterns and make sense of the Distance Stones in relation to the Wall's construction is laudable, it is reliant upon a complete material record that we do not possess. Later investigations largely followed this model and utilised Macdonald's interpretation of historical accounts of recovery contexts, some of which is demonstrably selective (see Appendix I). In order to undertake an exploration of alternative perspectives new approaches must be developed to address old problems, commencing with the application of a consistent methodology for extracting meaningful data from the Distance Stones.

Inclusion of the phrase $M P$ on another class of inscriptions that record distance, e.g. Milestones, is universally accepted as an abbreviation of Millia Passuum $\mathbf{= 1 , 0 0 0}$ paces $=\mathbf{1}$ mile. Milestones from Roman Britain confirm the practice of inserting $M P$ to record number of miles from the inscription's placement to a stated location ${ }^{23}$. For instance, RIB 2299 from the Stanegate close to Vindolanda records a distance of $M P$ XIIII (14 miles) to Corbridge; RIB 2306 from the Military Way on Hadrian's Wall at Milecastle 42 records $M P$ XVIII (18 miles) to Portgate at the junction of Dere Street; RIB 2274 from Castleford records M P XXII (22 miles) to York; and RIB 2244 from the Fosse Way near Thurmaston records M P II (2 miles) to Leicester. The practice is evident on other examples, including RIB 2283, 2243, 2265, 2272, 2235, 2241, 2312 and 3526 (see Table 2).

Thus, we are immediately presented with a previously undetected problem. There is a clear dichotomy in the way measurements are traditionally interpreted on distance markers elsewhere and the Antonine Wall Distance Stones where the full term is, uniquely, translated as defining only paces $^{24}$. In other words, established practice for the Antonine Wall Distance Stones unconsciously renders the first segment of the phrase (Millia) redundant in translations, despite it forming the linchpin of long accepted arguments

COLLINGWOOD/WRIGHT 1965

BATES 1898, 107-109. 


\begin{tabular}{|c|c|c|c|c|c|c|c|c|c|c|c|c|c|c|}
\hline 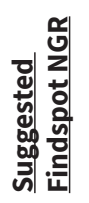 & $\begin{array}{l}\vec{n} \\
0 \\
0 \\
0 \\
n \\
0 \\
5 \\
z\end{array}$ & $\begin{array}{l}\frac{9}{5} \\
\hat{N} \\
\dot{6} \\
n\end{array}$ & 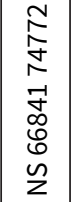 & 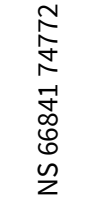 & 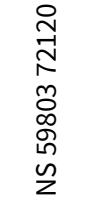 & 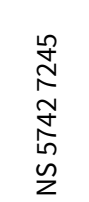 & $\begin{array}{l}\stackrel{I}{N} \\
\mathbb{N} \\
\mathbb{N} \\
N \\
\simeq \\
Z\end{array}$ & $\begin{array}{l}\infty \\
\stackrel{N}{N} \\
0 \\
\mathbb{N} \\
N \\
\tilde{n}\end{array}$ & 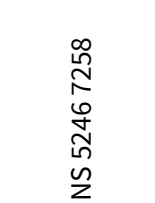 & $\begin{array}{l}\text { N } \\
0 \\
\underline{n} \\
\tilde{n} \\
z\end{array}$ & 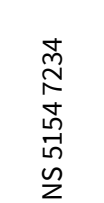 & 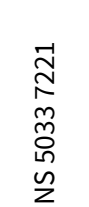 & $\begin{array}{l}\stackrel{a}{N} \\
N \\
-\vec{N} \\
g \\
\tilde{g}\end{array}$ & 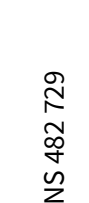 \\
\hline 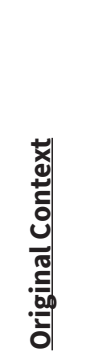 & 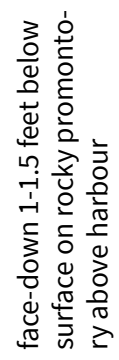 & 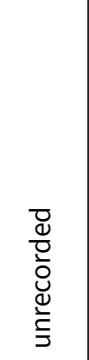 & 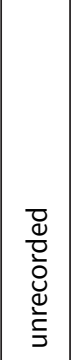 & 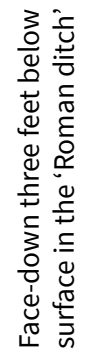 & 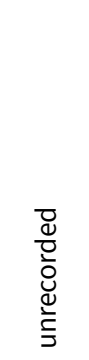 & 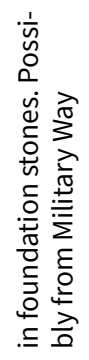 & 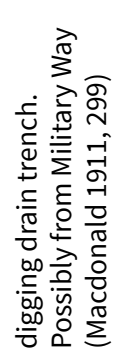 & 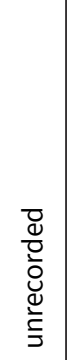 & 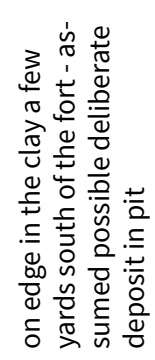 & 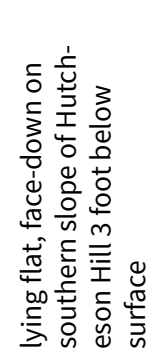 & 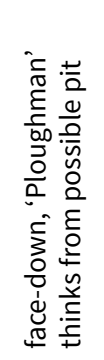 & 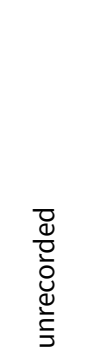 & 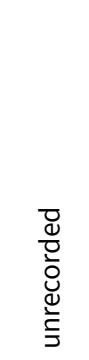 & 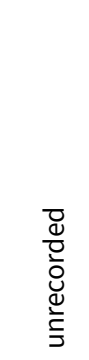 \\
\hline 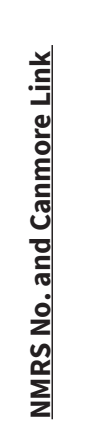 & 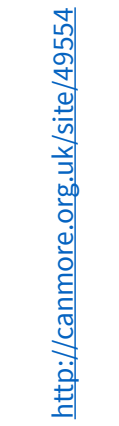 & 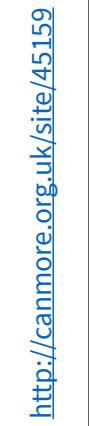 & 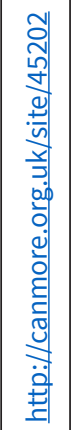 & 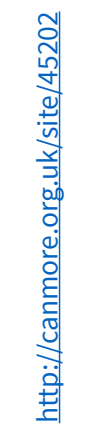 & 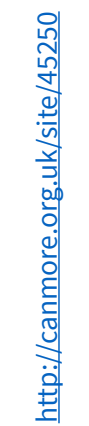 & 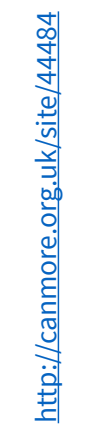 & 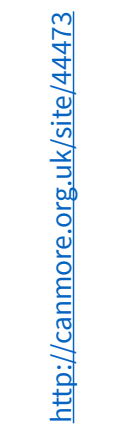 & 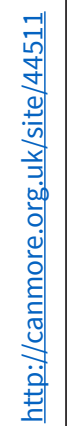 & 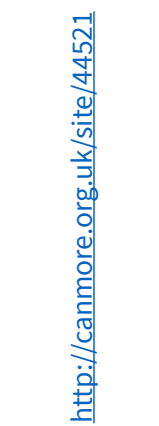 & 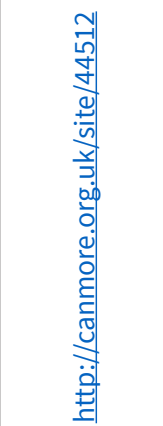 & 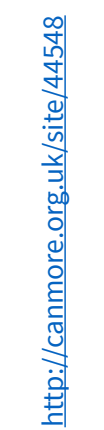 & 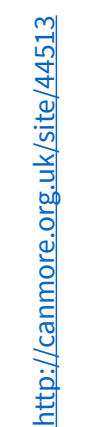 & 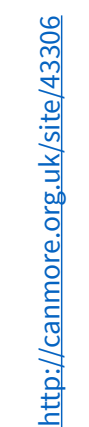 & 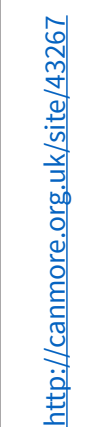 \\
\hline 해믈 & $\stackrel{9}{7}$ & ১ & $\curvearrowright$ & F & $\tilde{6}$ & $\widetilde{6}$ & $\stackrel{2}{\sim}$ & $\stackrel{2}{\sim}$ & ก & $\hat{\imath}$ & $\stackrel{t}{\wedge}$ & $\stackrel{2}{2}$ & 요 & గn \\
\hline 妾 틀 & 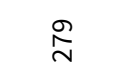 & ลิ & 㽞 & 요 & 욱 & 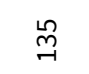 & $\stackrel{\text { 寽 }}{-1}$ & $\underset{G}{\stackrel{g}{G}}$ & $\stackrel{0}{2}$ & $\stackrel{\infty}{\infty}$ & $\stackrel{n}{\circ}$ & 가 & 간 & $\ddot{6}$ \\
\hline$\frac{\alpha}{\bar{y}}$ & & $\stackrel{\infty}{\stackrel{\leftrightarrow}{\rightarrow ~}}$ & & $\underset{\sim}{\sim}$ & 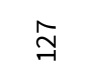 & $\stackrel{\hat{m}}{q}$ & & $\stackrel{\text { 号 }}{4}$ & $\stackrel{0}{d}$ & $\stackrel{\infty}{\underset{\sim}{\sim}}$ & $\stackrel{g}{G}$ & 号 & กี & 鴶 \\
\hline 비 & $\begin{array}{l}\infty \\
\stackrel{\infty}{-1} \\
-1\end{array}$ & $\underset{\exists}{\stackrel{?}{F}}$ & $\vec{I}$ & $\underset{\exists}{\mathbb{Z}}$ & 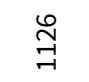 & 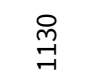 & $\underset{\vec{g}}{\vec{y}}$ & $\underset{\widetilde{m}}{\exists}$ & $\stackrel{m}{\stackrel{m}{7}}$ & $\stackrel{\widetilde{m}}{\underset{\exists}{7}}$ & & 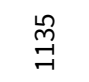 & $\stackrel{\infty}{\underset{7}{7}}$ & $\underset{\substack{--1}}{0}$ \\
\hline$\underline{\underline{\alpha}}$ & 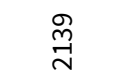 & 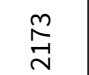 & $\mid \begin{array}{l}\llcorner \\
\infty \\
\sim \\
\end{array}$ & 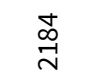 & $\begin{array}{l}\infty \\
\stackrel{\infty}{N} \\
\stackrel{N}{N}\end{array}$ & $\stackrel{m}{\vec{N}}$ & $\stackrel{+}{\stackrel{N}{N}}$ & $\begin{array}{l}\mathscr{\circ} \\
\stackrel{\sim}{n}\end{array}$ & ్ㅗ & $\stackrel{\infty}{\stackrel{\infty}{N}}$ & 总 & 워 & ڤ్ & 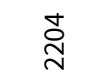 \\
\hline 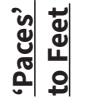 & $\begin{array}{l}\stackrel{0}{0} \\
\underset{N}{N}\end{array}$ & 吕 & 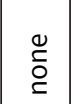 & 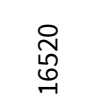 & 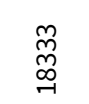 & 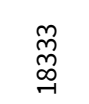 & 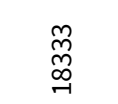 & 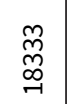 & ০ & ০্ল & 。্ & 荇 & 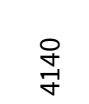 & 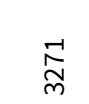 \\
\hline 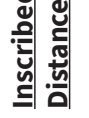 & 䒩 & : & 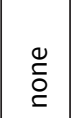 & 息 & $\begin{array}{l}n \\
\stackrel{0}{0} \\
\stackrel{0}{0} \\
m\end{array}$ & 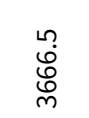 & $\begin{array}{l}n \\
0 \\
0 \\
0 \\
m\end{array}$ & $\begin{array}{l}n \\
0 \\
0 \\
e \\
m\end{array}$ & ষ্ণ & ০্ল & ঃ্̀ & 吕 & $\underset{⿱ 亠}{\stackrel{O}{\sigma}}$ & $\underset{m}{\vec{N}}$ \\
\hline 흠 & 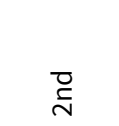 & 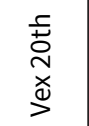 & 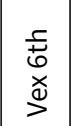 & 营 & $\stackrel{\bar{N}}{\text { L }}$ & 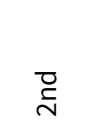 & 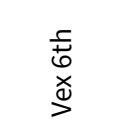 & 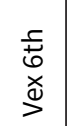 & 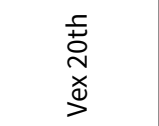 & 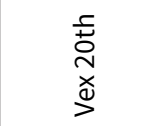 & 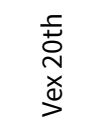 & 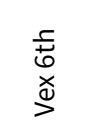 & $\stackrel{\square}{\sim}$ & 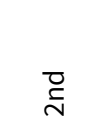 \\
\hline 部 & $\begin{array}{l}\infty \\
\stackrel{\infty}{0} \\
\rightarrow-1\end{array}$ & $\stackrel{0}{\stackrel{0}{0}}$ & 亭 & $\underset{\substack{D \\
\stackrel{D}{D}}}{ }$ & 过 & 旁兽 & $\begin{array}{l}m \\
0 \\
-1\end{array}$ & $\begin{array}{l}0 \\
\stackrel{0}{0} \\
-1\end{array}$ & $\underset{\substack{f \\
\rightarrow}}{\tilde{f}}$ & $\begin{array}{l}\stackrel{\sim}{0} \\
\stackrel{\infty}{\rightarrow}\end{array}$ & $\begin{array}{l}\stackrel{8}{\circ} \\
\stackrel{-}{-1}\end{array}$ & $\underset{\infty}{\stackrel{\sim}{\sim}}$ & 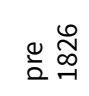 & 음 \\
\hline$\varepsilon$ & 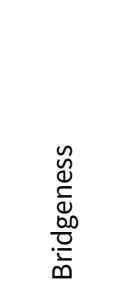 & 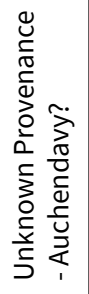 & 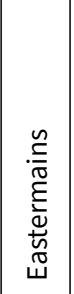 & 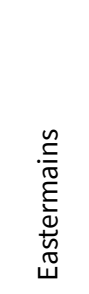 & 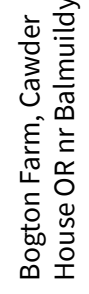 & 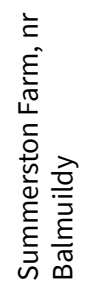 & 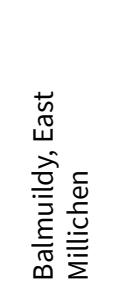 & 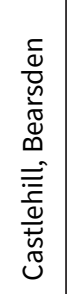 & 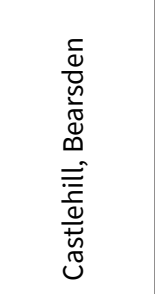 & 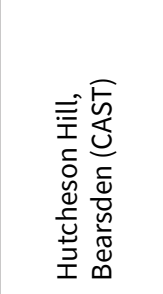 & 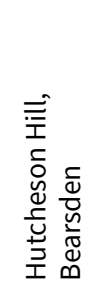 & 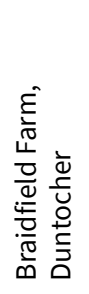 & 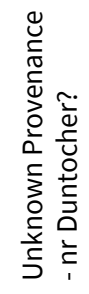 & 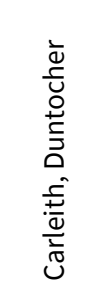 \\
\hline 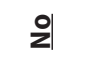 & $\rightarrow$ & ? & $m$ & $\theta$ & in & 0 & $r$ & $\infty$ & $\sigma$ & 욱 & $\vec{F}$ & ᄀ & $\stackrel{m}{\rightarrow}$ & $\underset{G}{\Delta}$ \\
\hline
\end{tabular}


for the Wall's construction sequence in the east referring to thousands of paces as opposed to feet in the west. To clarify, the Summerston Farm Distance Stone (no. 6) records " $M P$ IIIDCLXVIS", customarily interpreted as $3666^{1 / 2}$ paces $^{25}$, equal to 3 and 2/3 miles. However, if translated according to the actual inscription and consistent with widely accepted practice for other distance markers, the phrase $\underline{\boldsymbol{M} \boldsymbol{P}}$ in its entirety is equal to 1 mile (1000 paces), this measurement, in fact, translates to $3666 \frac{1}{1} 2$ miles.

Since the distances recorded immediately after ' $M$ $P^{\prime}$ on the Antonine Wall inscriptions cannot reasonably be argued to record thousands of miles, an alternative explanation could be that $M P$ translates to Millia Passuum (1000 paces) $=1$ mile, but refer only to an original standard template of numbers inscribed on all Distance Stones ('II' or 'III') with additional numbers added later relating to new practices of defining precise distances in feet. At first glance the inscriptions contain no indication of this practice, but the inclusion of a line above the initial III or IIII might support the hypothesis since this practice articulates 'thousands' in the measurements ${ }^{26}$, except for no. 2 which also uniquely contains the entire phrase 'MIL P'. Indeed, taking this point to a logical conclusion, the incorporation of both $M P$ and the line above initial numerals achieve the same aim and therefore duplicate meaning and, ultimately, making the measurement thousands of thousands of paces - an entirely unreasonable proposition and a practice that is not evident on any of the other markers of distance noted above and in Table 2 which are all devoid of any line above.

$M P$ on nos 1-8 may then alternatively refer to the same unit of measure ( $P$ for pedes - feet) as on all other examples, but stonemasons accustomed to inscribing $M P$ on monumental texts marking distances elsewhere continued that habit when construction began on the eastern sector of the Wall. In other words, a manifestation of practice through repetitive action on the part of inscribers replicating familiar formulae ${ }^{27}$. This offers a potentially plausible explanation since another known alternative to $M P$ on distance markers elsewhere in the Empire is $L$ for Leuga used in Germania ${ }^{28}$. Introduction of new practices is bolstered through the incorporation of $P$ or $P P$ in the examples from no. 9 onward which are normally translated as pedes. Here an intriguing pattern emerges where the first $P$ of the phrase $P P$ on those with single digit distances appears to replace Millia for thousand which contain a standard measurement of III (nos 9-11). Others recording lengthier distances contain only a single $P$ (nos 12-15) though both, again, contain the line above indicating 'thousand'. The exception to this is no. 17 which contains $P$ P (no. 16 is incomplete), see Table 3 , and note the proposals below relating to nos. 12 and 15 .

A similar practice could then reasonably be extrapolated as the intention for those examples containing M P. For example, nos 1 (with a distance of 4652), 4 (with a distance of 3304) and 5-8 (with a distance of $3666^{1 / 2}$ ) should merely have been inscribed with $P$ to denote Pedes (feet), while no. 3 , which is incomplete, should perhaps have been

${ }^{25}$ MACDONALD 373-6; KEPPIE 1998, 77-78.

26 BRUUN/EDMONDSON 2014, 813.

27 SAUER 2014, 261.

${ }^{28}$ KOLB 2019, 14; GREWE 2013, 2. 
Table 2. Roman Milestones from Britain.

\begin{tabular}{|c|c|c|c|c|c|c|}
\hline$\underline{\text { RIB }}$ & Found at & Distance from & Inscribed Distance (MP) & Distance (Miles) & Emperor & Date (AD) \\
\hline RIB 2283 & Kirkby & Carlisle & LIII & 53 & unknown & unknown \\
\hline RIB 2299 & Stanegate & Corbridge & XIIII & 14 & Severus Alexander & $222-3$ \\
\hline RIB 2243 & Silverlands & Brough-on-Noe & $\mathrm{XI}$ & 11 & unknown & unknown \\
\hline RIB 2306 & Milecastle 42 & Portgate/Dere St & $\mathrm{XVIII}$ & 18 & Severus Alexander & $222-3$ \\
\hline RIB 2274 & Castleford & York & XXII & 22 & Gallus \& Volusian & $251-3$ \\
\hline RIB 2265 & Caegwag & Caerhun & VIII & 8 & Hadrian & $120-21$ \\
\hline RIB 2272 & Artie Beck & unknown & IIII & 4 & Hadrian & $119-38$ \\
\hline RIB 2244 & Thurmaston & Leicester & II & 2 & Hadrian & $119-20$ \\
\hline RIB 2235 & Castor & Castor & 1 & 1 & Florian & 276 \\
\hline RIB 2241 & Lincoln & Littleborough & XIIII & 14 & Victorinus & $268-70$ \\
\hline RIB 2312 & Ingliston & Newstead & unknown & & Antoninus Pius & $140-4$ \\
\hline RIB 3526 & Brougham Castle & Carlisle & XVIIII & 19 & Severus Alexander & $222-3$ \\
\hline
\end{tabular}

inscribed with $P$ P (probably intended to have a distance of 3000 , see discussion below), while no. 2 is the only example incorporating the longer abbreviation of 'MIL'.

Addressing the issue from a purely statistical perspective may simplify the matter. When the proposal for paces (passus) as a unit of measure east of Castlehill (nos 1-8) is converted to equivalent Roman feet (pedes) as traditionally proposed for nos 9-18 (except for nos 12 and 15, for the reasons explained below), a disproportionate and potentially unrealistic allocation of labour emerges of proposed worksectors between 3000 and 23,260 feet in length (Fig. 2). Conversely, assuming a consistent unit of measure draws out a pattern of relative uniformity and results in distances falling between 3000 and 4652 feet (Fig. 3), a manageable and relatively equally proportionate programme of work for troops assigned to construct the frontier infrastructure that Macdonald ${ }^{29}$ accepts would have been normal practice.

A contradiction then exists to be confronted. On

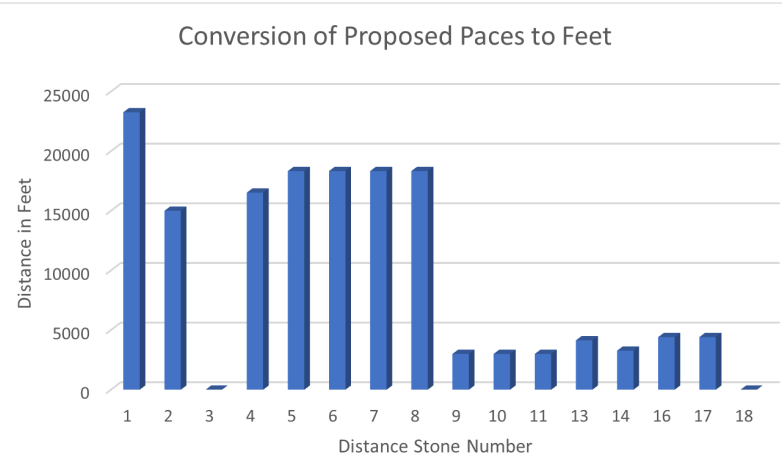

Fig. 2. Conversion of assumed paces (passus) east of Castlehill (nos 1-8) into feet (pedes).

the one hand, and on paper, it is proposed that subdivision into 15 work-sectors (Fig. 4) would have facilitated an easy distribution of construction between the three legions

\footnotetext{
${ }^{29}$ MACDONALD 1934, 380.
}

tasked with building the frontier ${ }^{30}$. On the other hand, deconstructing established terminology (paces and feet) and extrapolating these with precision into distances covered reveals an unrealistic partitioning of that labour. The coefficient variation of distances indicates a high variation (71.5\%) in the lengths of Wall constructed if measurements are expressed in feet based on a multiple of five for nos 1-8 (Table 3). Conversely, the standard of measurement is ubiquitous if taken as the same unit of measure.

Macdonald ${ }^{31}$ inadvertently validates this proposal by

Inscribed Distances - expressed in same unit of measure

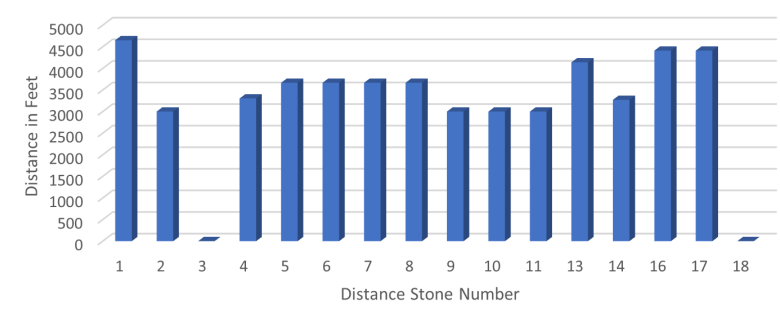

Fig. 3. Unit of measure in feet (pedes).

positing the absence of numerals after $M P$ on no. 3 should be interpreted as recording "only a single mile". That hypothesis allows him to slot this inscription into his sequence of the Wall's construction, but it is very clearly an example of an unfinished inscription ${ }^{32}$. Critically, he recognises that the term in its entirety translates to one mile and confirms normal practice is to take all numerals following $M P$ to signify number of miles.

Therefore, for the purposes of this paper and as a logical means for both the modern and ancient observer to meaningfully engage with them, the inscribed numerals on the Antonine Wall Distance Stones shall herein be taken to collectively refer to the same unit of measure (probably feet -

\footnotetext{
30 KEPPIE 1976, 59.

31 MACDONALD 1934, 367.

${ }^{32}$ KEPPIE 1974, 152.
} 
Table 3. Statistics and Coefficient Variation of Measured Distances.

\begin{tabular}{|c|c|c|c|c|}
\hline $\begin{array}{l}\text { Distance } \\
\text { Stone } \\
\text { No. }\end{array}$ & $\begin{array}{l}\text { Roman } \\
\text { Numerals }\end{array}$ & $\begin{array}{l}\text { Inscribed } \\
\text { Distance }\end{array}$ & $\begin{array}{l}\text { Paces to } \\
\text { Feet }\end{array}$ & \\
\hline 1 & M P IIIIDCL II & 4652 & 23260 & \\
\hline 2 & MIL P III & 3000 & 15000 & \\
\hline 4 & M P III P IIICCCIV & 3304 & 16520 & \\
\hline 5 & M P III DCLXVIS & 3666.5 & 18332.5 & \\
\hline 6 & M P III DCLXVIS & 3666.5 & 18332.5 & \\
\hline 7 & M P III DCLXVIS & 3666.5 & 18332.5 & \\
\hline 8 & M P III DCLXVIS & 3666.5 & 18332.5 & \\
\hline 9 & P P III & 3000 & 3000 & \\
\hline 10 & P P III & 3000 & 3000 & \\
\hline 11 & P P III & 3000 & 3000 & \\
\hline 13 & P IIII CXL & 4140 & 4140 & \\
\hline 14 & P III CCLXXI & 3271 & 3271 & \\
\hline 16 & [P P IIII C]DXI & 4411 & 4411 & \\
\hline 17 & P P IIII CDXI & 4411 & 4411 & \\
\hline & & 4652 & 23260 & Max \\
\hline & & 3632.5 & 10953.071 & Mean \\
\hline & & 3000 & 3000 & Min \\
\hline & & 578.62599 & 7832.0656 & Stdev \\
\hline & & 15.929139 & 71.505656 & $\begin{array}{l}\text { Coefficient } \\
\text { Variation } \\
(\%)\end{array}$ \\
\hline
\end{tabular}

pedes) without burdening interpretations with mathematical computations that have vexed scholars since the $17^{\text {th }}$ century, Fig. 4. This is not an unreasonable proposition since inscriptions associated with other limites such as along the Tiber at Rome ${ }^{33}$ and municipal aqueducts ${ }^{34}$ refer to feet ${ }^{35}$. This model has the benefit of creating ample space for any future discoveries to be slotted into the construction sequence.

Although an invaluable schematic, Keppie's plan of proposed building sectors (Fig. 4) is based on extrapolation for the entire eastern section of the Wall as indicated by the incorporation of question marks for sectors 2-5. In fact, Bridgeness (no. 1) is the only Distance Stone known to have been recovered east of Cumbernauld since no. 21 is missing and no. 19 survives only as a fragment so neither can be definitively identified as a Distance Stone (Fig. 5). Therefore, alternative interpretations may now be offered that cast doubt upon long-established proposals for the work sectors. It could be argued that the recovery of almost all examples from west of the Wall's centre is serendipitous and relates to farm management practices to the south of the monument.

\footnotetext{
33 CIL vi. pp. 3111.

${ }^{34}$ CIL vi, pp. 3123.

35 MACDONALD 1911, 270.
}

There is not the space here to provide detailed descriptive accounts of the Distance Stones, a task that has been admirably achieved by Professor Lawrence Keppie ${ }^{36}$. Instead, a brief overview of each sculpture summarising key points of note and discovery contexts is contained in Appendix I (see also Table 1 for annotated information). Fig. 6 provides digital images so that they can be considered holistically in their current condition in as much detail as possible. Numbering is assigned in line with Keppie ${ }^{37}$ who conforms broadly with Macdonald's ${ }^{38}$ system, except for nos. 11-14 which have necessarily altered due to the later discovery of no. $11^{39}$ and the assignation of numbers to 19-21, previously discussed only in brief by Macdonald ${ }^{40}$. References to "(the Wall)" in Keppie's translations of inscriptions have been removed unless the mural barrier is explicitly mentioned in the inscribed text ${ }^{41}$.

\section{READING THE WRITING ON THE WALL: DECONSTRUCTING THE CONSTRUCTION}

None of the Distance Stones have been recovered from their original contexts. Since most were found between the seventeenth and nineteenth centuries historical records of their contexts of discovery lack precision, though descriptive accounts for several permit a reasonable extrapolation of findspot locations and contextual information. Cramp-holes on the sides and tops of most confirm they must have been embedded into a masonry frame or platform ${ }^{42}$ and they are thought to record sectors of the Antonine Wall constructed by the Legions commemorated in the inscribed texts. It is further assumed that detachments from the three named Legions were assigned to the construction work ${ }^{43}$. In reality, all but one of those attributed to the $20^{\text {th }}$ Legion and all those of the $6^{\text {th }}$ Legion record a vexillation (detachment). None of the $2^{\text {nd }}$ Legion inscriptions mention vexillations, leading Macdonald ${ }^{44}$ to surmise that this was the only Legion stationed on the Wall at full strength, though this is disputed by Strang ${ }^{45}$ and see comments relating to no. 4 , below.

Duplication of recorded measurement on several examples is deeply enigmatic, especially when they refer to oddly specific distances ${ }^{46}$ as this does not conform to normal Roman practice. For example, 3666 1/2 inscribed on two from the $2^{\text {nd }}$ Legion (no. 5, Cawder House, and no. 6, Summerston Farm) and two from detachments of the $6^{\text {th }}$ Legion (no. 7, East Millichen near Balmuildy, and no. 8, Castlehill). It has been suggested that more than one inscription was commissioned to commemorate a single length ${ }^{47}$.

More striking is a pattern of replication evident in the $20^{\text {th }}$ Legion's inscriptions, including no. 2 of unknown
36 KEPPIE 1979; 1998.
37 KEPPIE 1979.
38 MACDONALD 1934.
39 STEER/CORMACK 1969.
40 MACDONALD 1934, 392.
${ }^{41}$ Only nos 12 and 15.
42 KEPPIE 1976, 63.
43 KEPPIE 1998, 51.
44 MACDONALD 1911, 295.
45 STRANG 2007, 14.
${ }^{46}$ HASSALL 1983
47 GLASGOW ARCHAEOLOGICAL SOCIETY 1899, 9.
48 after KEPPIE 1979, 6.
49 Map kindly produced by N Hannon from data recorded on Canmore at 


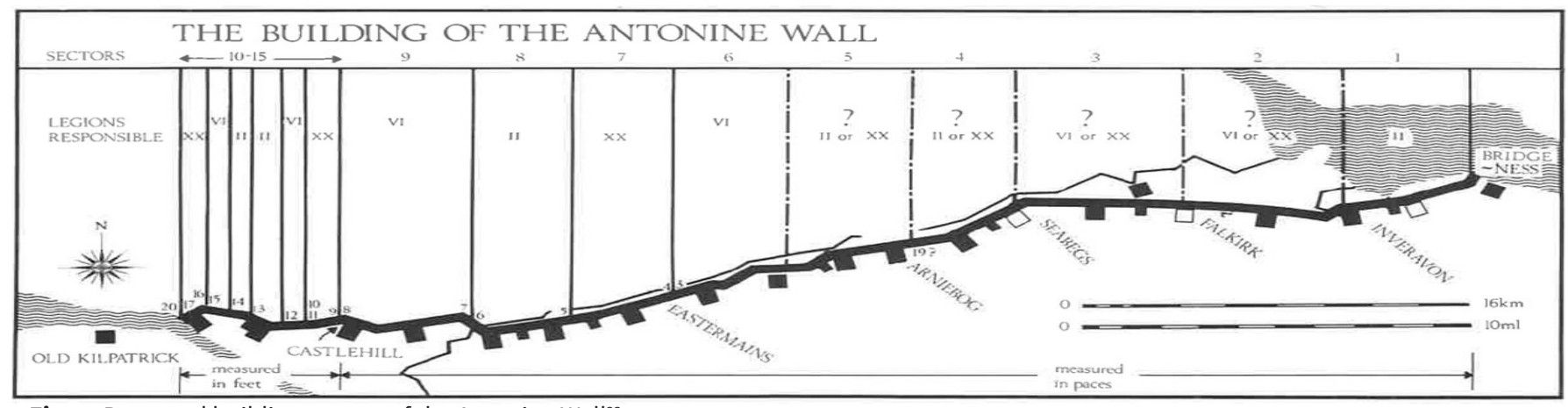

Fig. 4. Proposed building sectors of the Antonine Wall ${ }^{33}$.

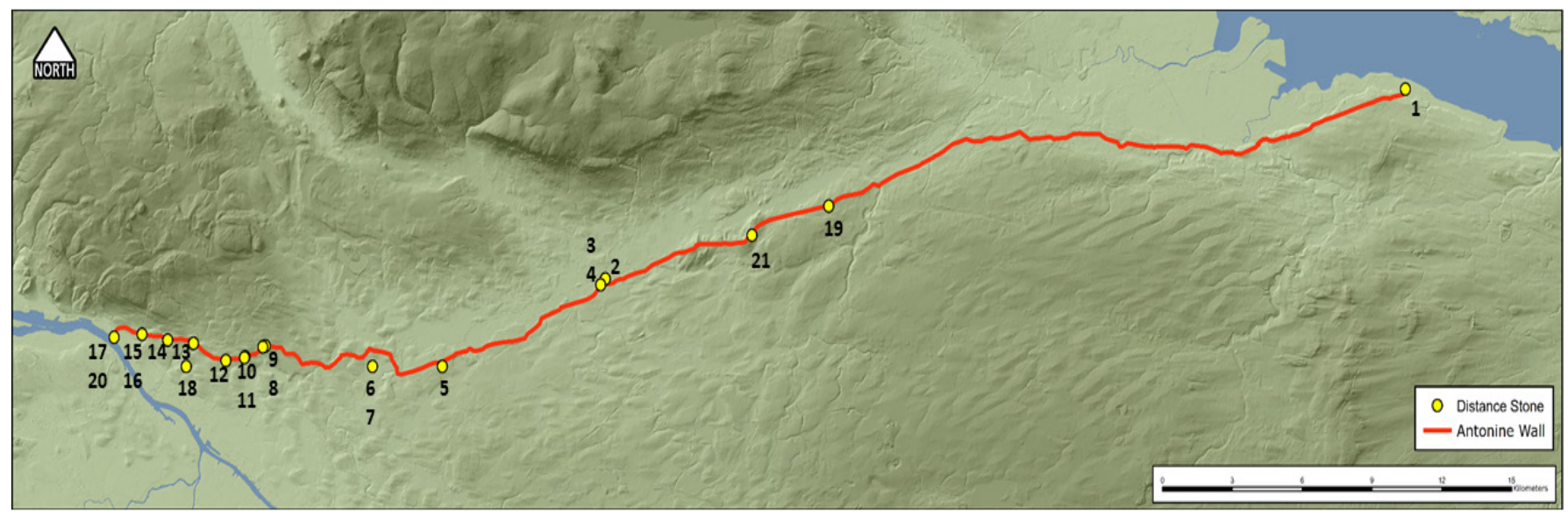

Fig. 5. Positions of Distance Stones findspots recorded on Canmore ${ }^{34}$

provenance but widely considered to have originated from Auchendavy (though, based on the inscribed distance correlating with practice on other examples from the $20^{\text {th }}$ Legion this may have originated from close to Castlehill fort), no. 9 from Castlehill and nos. 10 and 11 from Hutcheson Hill, all of which record a distance of 3000 . Another pair from the $20^{\text {th }}$ Legion recording a distance of 4411 were reportedly recovered from the vicinity of Old Kilpatrick at Dalnottar Burn (no. 16) and Ferrydyke (no. 17). On the surface, it appears only one foot separates the distances recorded on the $2^{\text {nd }}$ Legion's no. 13 from Duntocher (4140 feet) and no. 15 from Old Kilpatrick (generally translated as 4141 feet $^{50}$ ) dedicated by a detachment of the $6^{\text {th }}$ Legion. This led to a suggestion that the latter two could be a matched pair since the difference of just one foot may have been an erroneous omission on the inscribed distance by the stonemason ${ }^{51}$. However, this research suggests errors permeate traditional interpretations of the symbol (X) that appear only on these two examples, see below.

Another oddity is the $20^{\text {th }}$ Legion's no. 4 from Eastermains recording a distance of ' $M$ P III P IIICCCIV" taken to infer 3000 paces (and) 3304 feet, equating to 3660 $4 / 5$ paces which is close to the aforementioned measurement

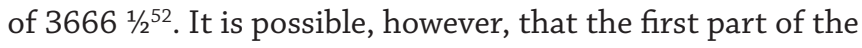
measured distance on no. 4 (3000) was erroneously repeated by the inscriber tasked with updating the inscription with precise distance on completion of work-sectors. This means that this Distance Stone might correctly be grouped with

https://canmore.org.uk/

${ }_{50}$ MACDONALD 1934, 389; KEPPIE 1998, 86.

${ }^{51}$ STRANG 2007, 15.

${ }^{52}$ KEPPIE 1998, 75. the $20^{\text {th }}$ Legion's other inscriptions marking an original standard distance of 3000 feet with the later addition of 304 accidentally, probably by a different inscriber, repeating the original 'III'. This original intent may be supported by the absence of 'PER' on no. 4, the only example referencing ' $M P$ ' (nos 1-8) that does not include the phrase.

These pairings may have been placed at either end of a completed section due to exact lengths of paired stones from closely affiliated find-spots ${ }^{53}$, but this seems implausible precisely because of the close proximity of some of their findspots, particularly three from Bearsden (nos. 9-11) along with, potentially, no. 2, marking 3000 units of measure and two from near Balmuildy (nos. 6 and 7) marking 3666 $1 / 2$. While it is possible their placement may have been one embedded into both the front and rear of the rampart at either end of a completed sector ${ }^{54}$, the recovery of all but possibly one (no. 4 recorded as from 'the Roman ditch'55) from south of the Wall cautions against that proposal which also, critically, runs counter to the ability of passers-by to encounter the inscription ${ }^{56}$. Further, how to explain the completion of exactly comparable lengths by the second and sixth Legions recording $36661 / 2$, above?

Perhaps an answer may be found by turning to inscription patterns of the Legions represented. Two were recorded as being recovered near Balmuildy, one each from the $2^{\text {nd }}$ (no. 6) and a detachment of the $6^{\text {th }}$ Legions (no. 7),

\footnotetext{
${ }_{33}$ MACDONALD 1934, 371.

54 KEPPIE 1998, 51.

55 STUART 1852, 325.

5 KEPPIE 1998, 49.

57 No. 1 (C) National Museum of Scotland; No. 7 (C) Glasgow Museums; Nos. 2, $3,4,6,9,10,11,12,13,15,17,18$ and 19 (c) Hunterian Museum.
} 


\section{Studies}

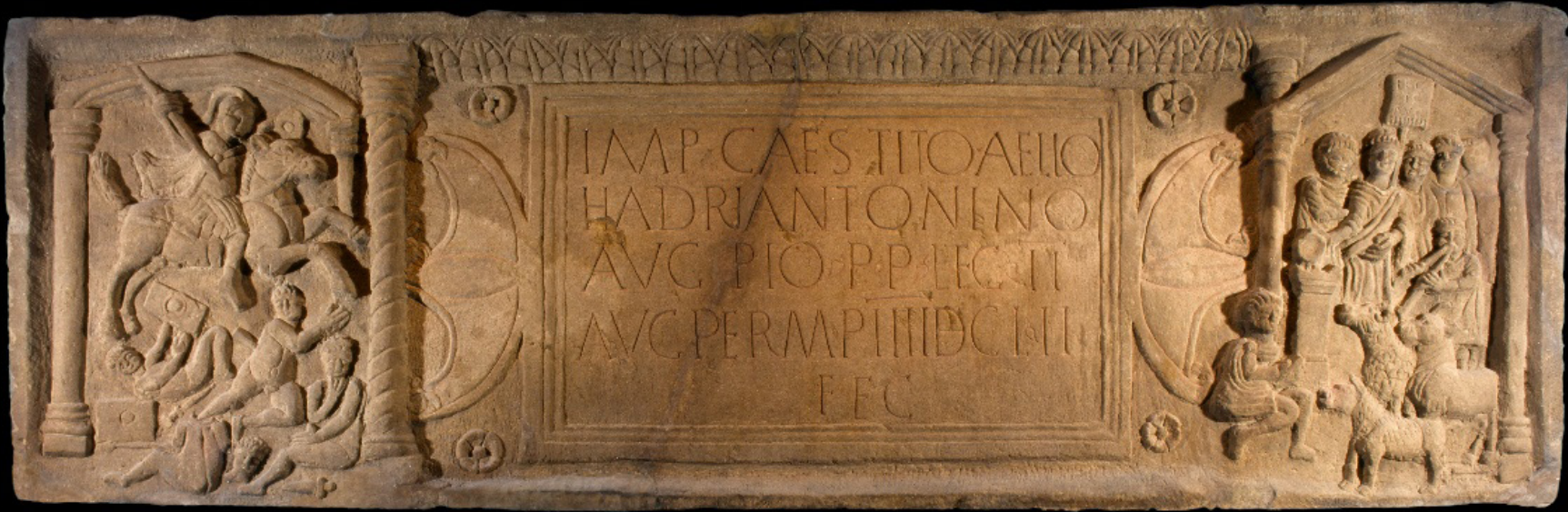

1
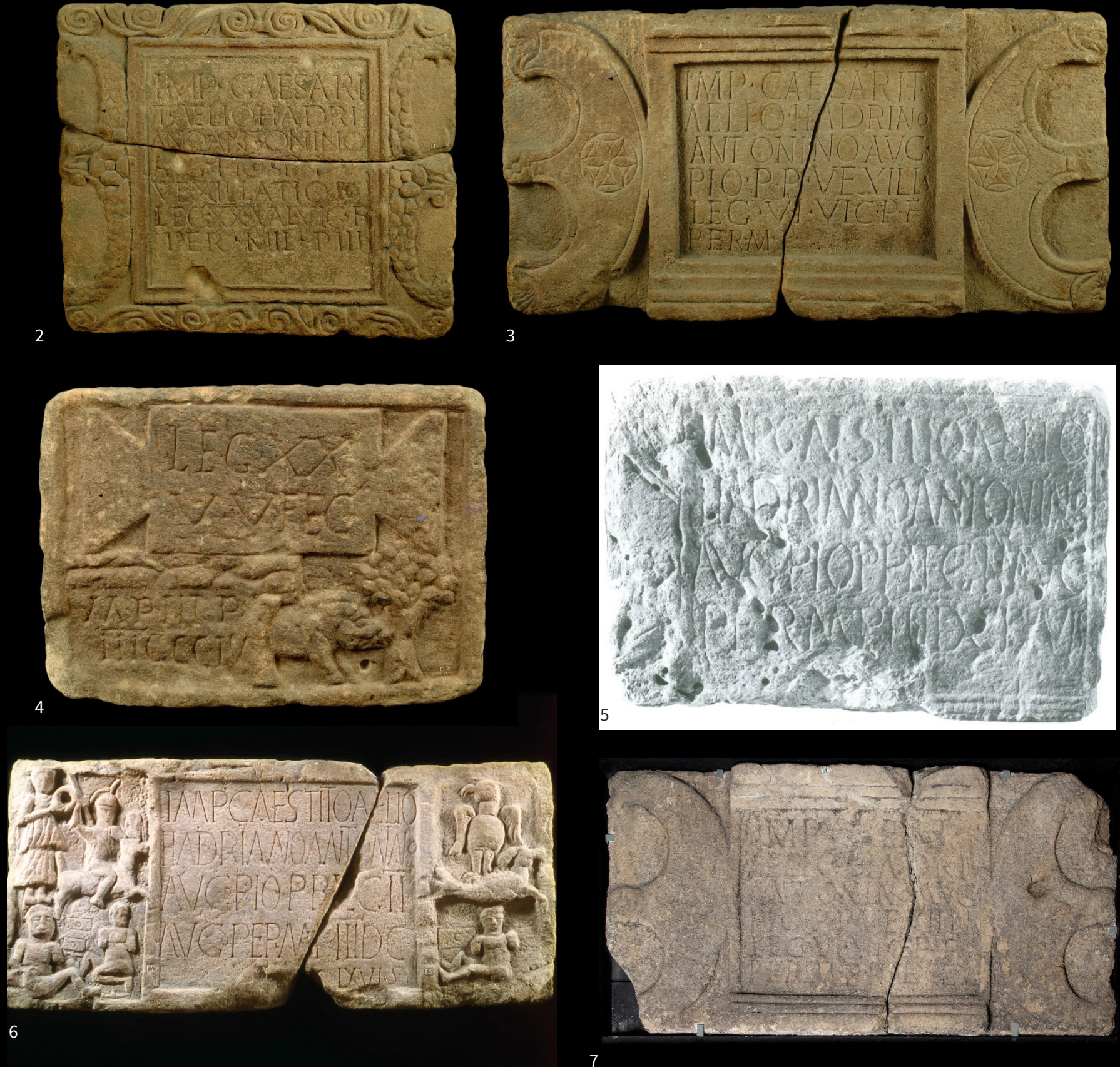


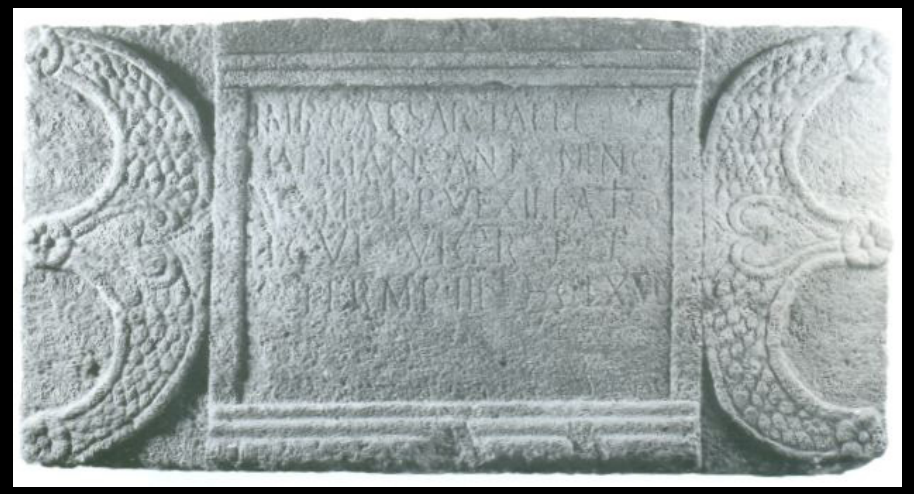

8

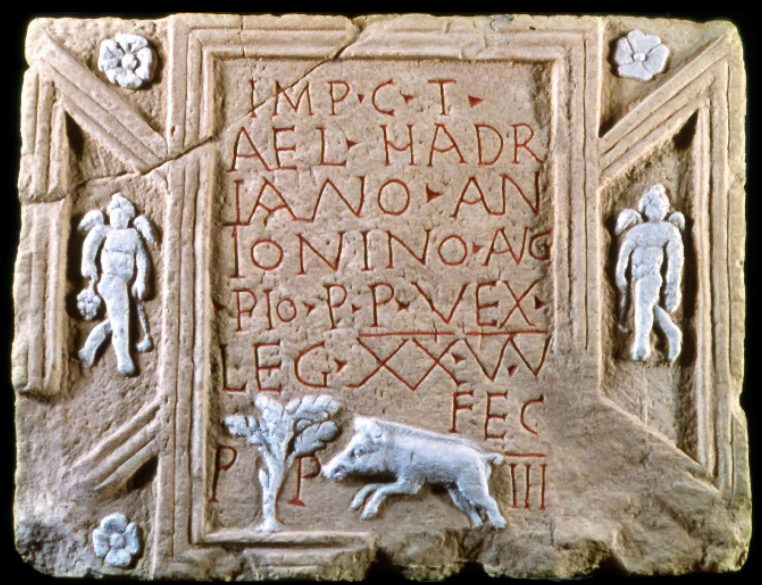

10
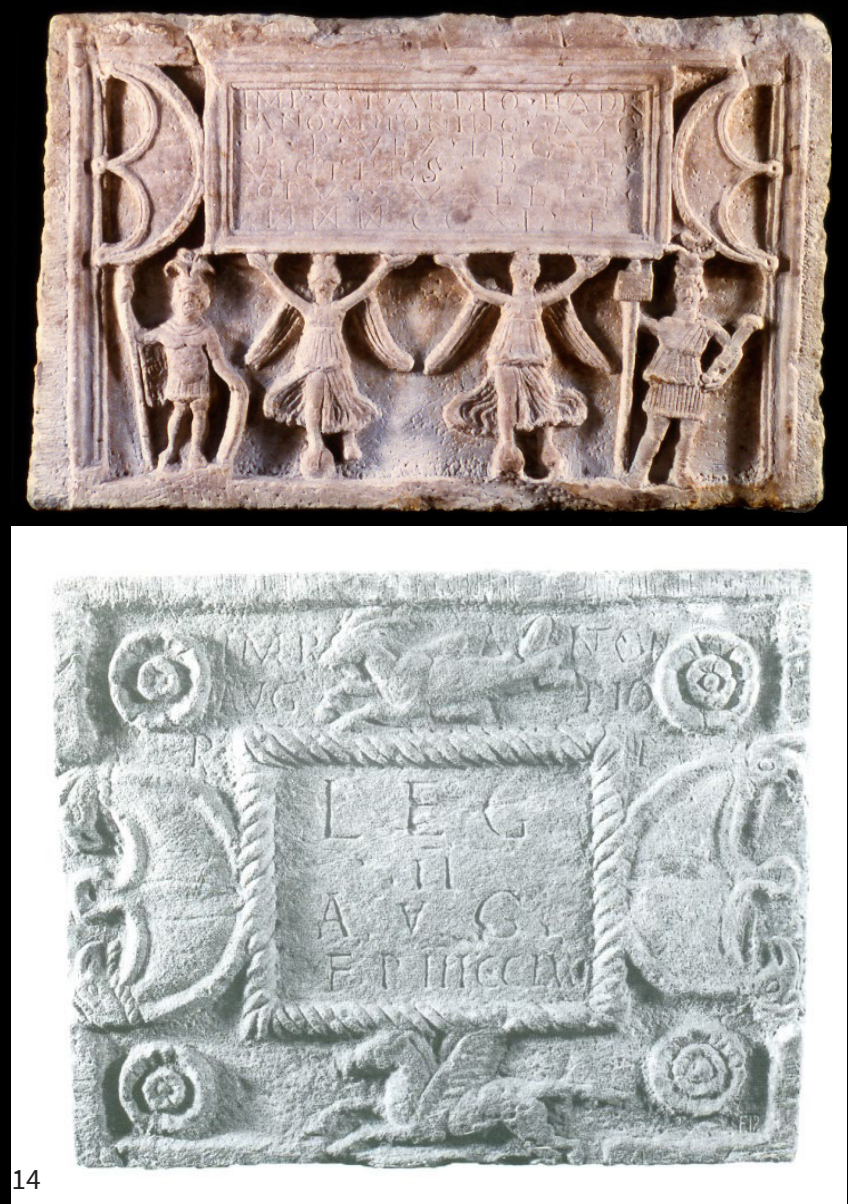
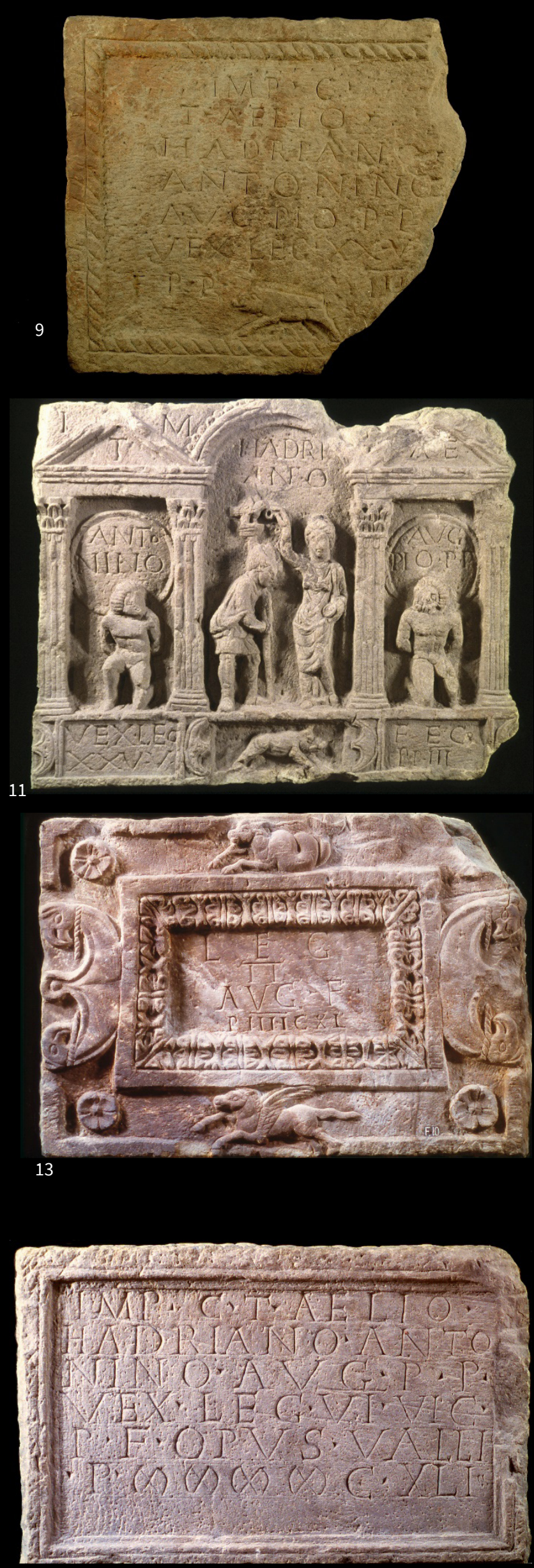


\section{Studies}
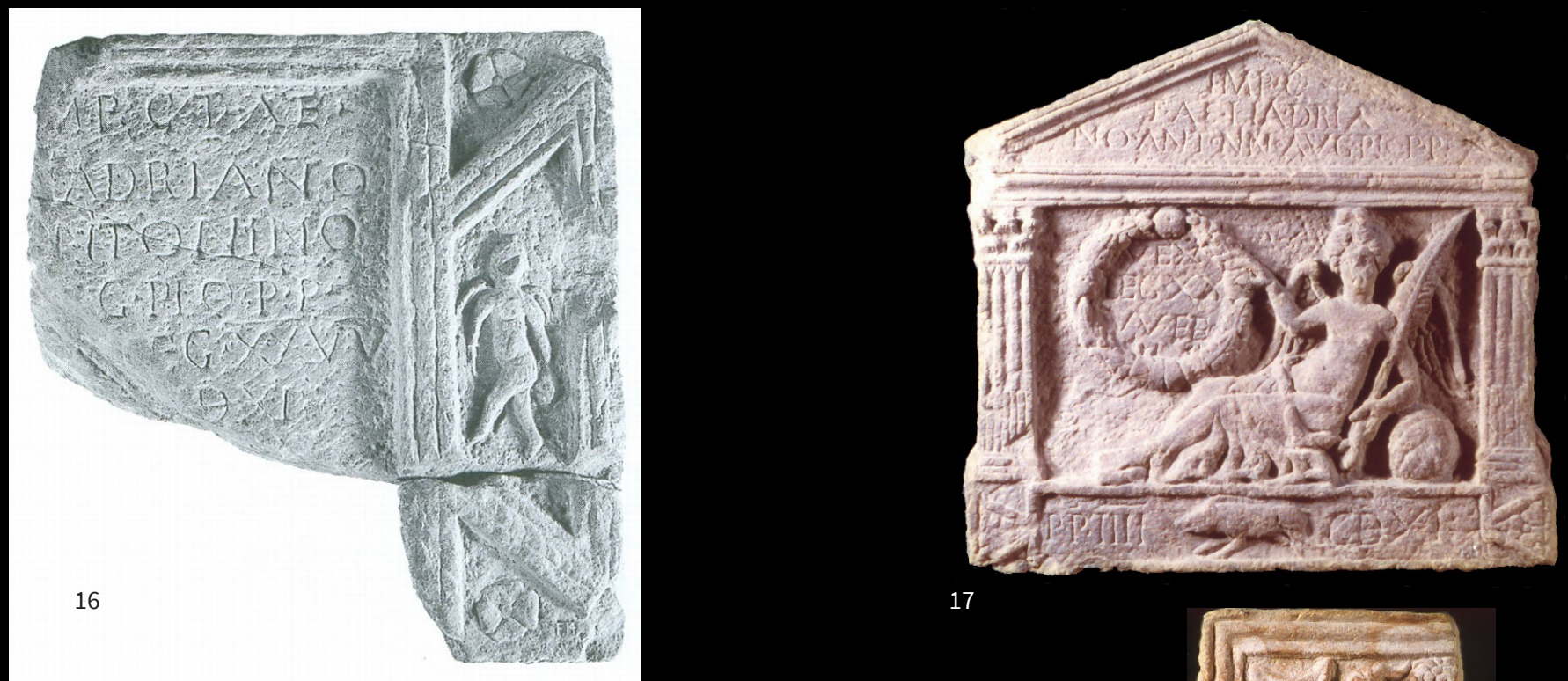

17

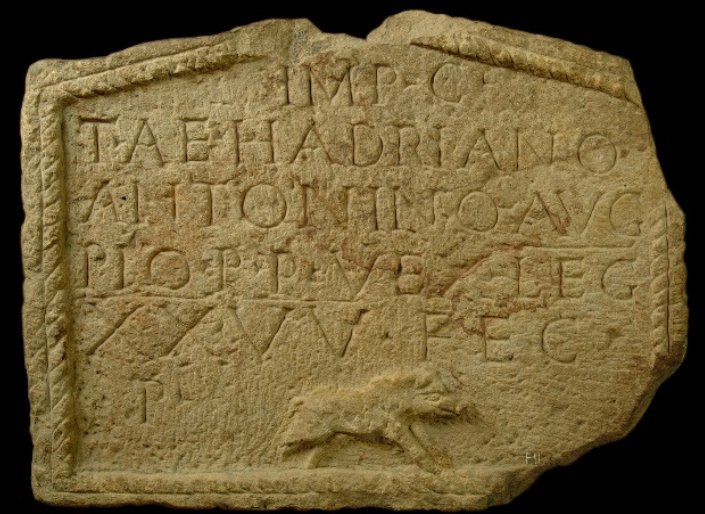

18

19

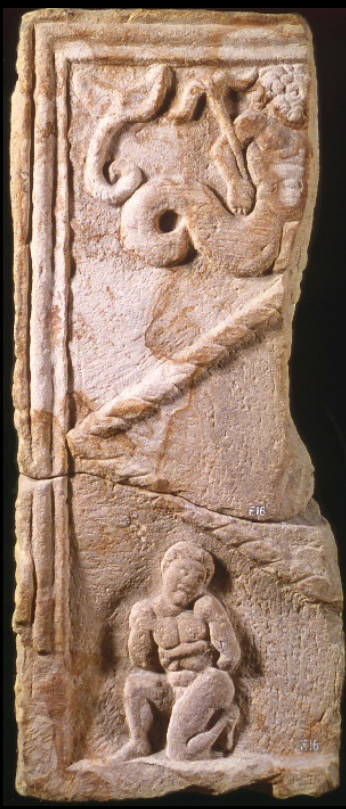

Fig. 6. The Antonine Wall Distance Stones.

and each have a proposed matched distance inscribed in either direction - to the east at Castlehill for the $6^{\text {th }}$ Legion (no. 8) and to the west at Cawder House, Bishopbriggs (no. 5) for the $2^{\text {nd }}$ Legion. However, the original context of discovery is not recorded for either. The situation is exacerbated for the latter since it was built into walls of Cawder House and the former was alternatively proposed to have originated from Summerston Farm ${ }^{58}$. Having accepted his predecessors' accounts for other important information, there seems no valid reason for Macdonald ${ }^{59}$ to argue against their suggestions that no. 5 derives from near Balmuildy except for the express purpose of substantiating his efforts to pair these four stones, one at either end of completed lengths. Indeed, it would be an inconvenient truth for Macdonald's hypotheses if no. 5 was recovered from close to Balmuildy since it would be the source for three of the four.

Alternatively, might we have found in Balmuildy the base for a stonemason who crafted the sculptures and later

${ }_{58}$ MONUMENTA ROMANI IMPERII 1768; ANDERSON 1771, 33.

${ }^{59}$ MACDONALD 1934, 271. he, or indeed someone else, updated distances by squeezing in an extra $666 \frac{1}{1} 2$ after an original standard inscription of 3000 ? Or, since two of the three commemorate the $2^{\text {nd }}$ Legion and the other two detachments of the $6^{\text {th }}$ Legion, do they validate Macdonald's proposal for one at each end of a stretch of construction in one direction and an additional reference to a section constructed by the $2^{\text {nd }}$ (at full complement) in the other direction? I.e., a stretch constructed by the $6^{\text {th }}$ Legion from Balmuildy westward to Castlehill commemorated by nos. 7 and 8 and the $2^{\text {nd }}$ Legion constructing an eastern sector for $3666 \frac{1}{2}$ feet (no. 6) with its planned pair for the other end not yet moved from the stonemason's base to match the completed end of the section?

Another plausible, if controversial, explanation is their reference to sectors of work on different structures: the Wall and the Military Way. Macdonald originally considered the possibility of two legions working on different elements of the infrastructure side by side or even that different groups of men were assigned to construct the rampart, the ditch and 
the Military way ${ }^{60}$ though later revised this, concluding these groups referred to different sectors of the Wall ${ }^{61}$. Keppie also proposes that ditch-digging would have been unlikely to have been commemorated on the Distance Stones ${ }^{62}$. He does not make suggestions for how construction of the Military Way might have been commemorated, despite this being an equally integral component of the frontier infrastructure, though he suggests that laying down the Wall base, rampart construction and ditch digging need not have occurred simultaneously. Using the appearance of 'OPUS VALLI' only on nos 12 and 15 as examples, he makes the critical observation that it may be inappropriate to assume the same Legion undertook all tasks or that the Distance Stones "need testify to the completion of both"63. Conversely, Hanson and Maxwell ${ }^{64}$ mention work involved in the Military Way, though they do not hypothesise on how that construction may have been recorded. Macdonald broaches this in his first edition with the suggestion that no. 7 was "lying so far south of the Rampart may be due either to its having been carried or to its having originally stood on the line of the Military Way"65. He later excised this comment from his second edition $^{66}$ and it has not been subsequently picked up on.

It is, therefore, not too far a leap to suggest the use of MP on some of the Distance Stones might mark construction or repair of the Military Way, or at least may have been placed along it. Further, pairings of stones might have been placed at either side of the Way with one each facing east and west in the manner we remain familiar with in the present day.

It is also intriguing to note that all six of those dedicated by the $20^{\text {th }}$ Legion are formulaic insofar as at least four record 3000, plus one other candidate in no. 4 that could have originally recorded 3000 with additional measurements incorporated at a later date, and two record a distance of 4411 (nos 16 and 17). This cannot be coincidental. The practice firmly suggests Legions commissioned the inscriptions in advance of the completion of construction work with the intention that precise dimensions could be incorporated later as briefly touched upon by Keppie ${ }^{67}$. Certainly, these monumental inscriptions took time to create, particularly those incorporating sculptural detail. It is, therefore, conceivable that some inscribed stones were sculpted with distances partially completed with gaps left for distances to be added with precision on completion of work programmes. This might explain the less well articulated character of the numbers on many in comparison to the preceding inscribed standard templated distances (i.e. III or IIII).

The presence of two enigmatic examples lends credence to this hypothesis. Contrary to Macdonald's definition of no. 18 from Cochno Estate as a 'waster' since it is devoid of measured distance, it has been suggested ${ }^{68}$ this and no. 3 from Eastermains, also lacking measurement, were ultimately used on the Wall due to their recovery from its vicinity. We cannot

\footnotetext{
60 MACDONALD 1911, 295.

${ }^{61}$ MACDONALD 1934, 377.

62 KEPPIE 1974, 161-163.

${ }^{63}$ KEPPIE 1974, 163.

${ }^{64}$ HANSON/MAXWELL 1983, 130-133.

${ }^{65}$ MACDONALD 1911, 299.

${ }^{66}$ MACDONALD 1934.

67 KEPPIE 1998, 55

${ }^{68}$ KEPPIE 1998, 53
}

be certain of the findspot for no. 18 since it was built into a wall above the gate of Cochno Estate, while the findspot of no. 3 was half a mile east of Kirkintilloch fort. Critically, both examples are fully complete in all detail aside from the inclusion of distances common to others. They can therefore be confidently defined as unfinished inscriptions commissioned by detachments of the $20^{\text {th }}$ and $6^{\text {th }}$ Legions respectively that awaited only the incorporation of precise measurements prior to installation at an appropriate location ${ }^{69}$. The initial carving could have been undertaken at source quarries ${ }^{70}$, though these two examples were recovered some distance apart which makes this less likely or might suggest, at least, that they have been transported from the artisan workshop to locations close to their intended placement.

An intention to inscribe measurements after the initial sculpting of main features on the Distance Stones may also explain the squeezing in of dimensions onto some that otherwise contain properly set out text with relatively standard-sized lettering, such as nos. 5-8 and 14. Intriguingly, the former examples relate to those oddly specific measurement of $36661 / 2$ units. Were these originally intended to document 3000 feet, or even 3 miles (M P III), but later extrapolated to reflect a longer than anticipated stretch of construction or even structural repair to the same work-sectors $^{71}$ ?

This could explain, as hinted at above, the enigmatic inclusion of what was previously proposed as a combination of paces and feet onto no. 4 from Eastermains inscribed with "M P III / P IIICCCIV"72. This comparatively small and poorly executed example is the only Distance Stone from the $20^{\text {th }}$ Legion that does not stipulate a vexillation, neither does it contain a dedication to the Emperor, in common only with no. 13 from Carleith. Might this indicate the presence of the entire $20^{\text {th }}$ Legion, at least in an initial phase of construction? Macdonald ${ }^{73}$ reports both omissions but rationalises it as restrictions in available space due to the small dimensions of the stone coupled with the large size of inscribed letters. He further relies on Bates ${ }^{174}$ hypothesis of combined paces and feet to total $36604 / 5$ paces which cannot be expressed in Roman numerals, so he likens it to the $3666 \frac{1}{2}$ recorded on nos. 5-8. Again, this is a convoluted and uncharacteristic way of expressing measurements, especially when compared to established practice on other Roman markers of distance. It is perhaps more feasible to suggest either two distinct phases of work or an intention to undertake work equating to 3000 feet, in common with the others dedicated by the $20^{\text {th }}$ Legion, then the incorporation of accurate dimensions on completion of construction. Alternatively, perhaps we are over-thinking this conundrum which may simply be the result of an inexperienced scribe who should have followed the convention set with other examples of adding in the extra numerals after the standard measurement of 'III' but he has erroneously repeated the 'III', as suggested by Hübner ${ }^{75}$.

\footnotetext{
${ }^{69}$ contra HANSON/MAXWELL 1983, 126 who suggest the distance may have been written in paint

${ }^{70}$ KEPPIE 1998, 55.

${ }^{71}$ HÜBNER 1873, 193.

72 BATES 1898; KEPPIE 1979, 13.

3 MACDONALD 1934, 368.

BATES 1898.

${ }^{75}$ HÜBNER 1873.
} 


\section{MARKING THE MURAL BARRIER}

Two of the inscriptions stand apart from all others - no. 12 from Braidfield Farm near Duntocher and no. 15 from Old Kilpatrick - both dedicated by detachments of the $6^{\text {th }}$ Legion. These alone are inscribed with the phrase 'OPUS $V A L L I$ ' which is traditionally taken as an explicit reference to the Wall's construction ${ }^{76}$. The term could alternatively be interpreted as incorporating all the mural barrier's structural features, including the ditch ${ }^{77}$, although different elements of the infrastructure may have been constructed by different Legions ${ }^{78}$. Macdonald ${ }^{79}$ recognises that the specified measurements on the Distance Stones refer to "some piece of work - in two instances expressly defined as 'OPUS VALLI', the work of the Wall". Assumptions that the Distance Stones collectively, and solely, refer to constructed sectors of the Antonine Wall rest entirely upon these two texts which could legitimately be considered statistical outliers at less than $10 \%$ of the total collection. But caution should be exercised against hinging our interpretations of the collection based on just two examples. Indeed, the notion has been floated that 'OPUS VALLI' might alternatively refer to fort ramparts as opposed to the mural barrier ${ }^{80}$, though this is later dismissed by the writers. It could be argued that the absence of explicit reference to the structures associated with monumental texts is common practice in Roman inscriptions ${ }^{81}$ but that would raise the question what prompted the requirement for these two particular sculptures to make reference to the Wall when none others do, particularly since none were found on the Wall so any assignation of them to that structure is conjecture.

Although stylistically different, these two Distance Stones incorporate inscribed texts that differ only very slightly in the measurements recorded as well as the abbreviation of Victric(i)s on no. 12 compared to Vic on no. 15. There are other, equally striking, similarities between them that do not conform to any of the other Distance Stones. Firstly, these are the only examples containing dedications to the Emperor that do not include his title Pio (Pius), a point that Macdonald ${ }^{82}$ dismissively attributes to accident rather than ignorance.

Secondly, and more significantly, these are the only Distance Stones that incorporate the symbols '(X)' customarily translated to refer to thousands in the measured distances where all others use either III or IIII in reference to thousands. It is somewhat surprising that this latter point is not picked up on by Macdonald or others and only fleetingly referred to by Stuart ${ }^{83}$ and Keppie ${ }^{84}$. In reality, the (X) symbol more accurately translates as $10,000^{85}$ in Roman epigraphic practice meaning that these Distance Stones actually record a measured distance of 30,240 feet (no. 12) and 40,141 feet (no. 15) not 3240 and 4141, respectively, as traditionally accepted. This equates to a total of 70,381

\footnotetext{
76 HANSON/MAXWELL 1983, 113.

77 KEPPIE 1998, 51

78 KEPPIE 1974, 163.

79 MACDONALD 1934, 359.

${ }^{80}$ HANNON/ROHL/WILSON 2017, 7.

81 KEPPIE 1998, 49

${ }^{82}$ MACDONALD 1934, 385 and 389.

83 STUART1852, 288.

${ }^{84}$ KEPPIE 1998, 51, 84 and 86.

${ }^{85}$ BRUUN/EDMONDSON 2014, 813.
}

feet or $14,076.20$ paces, a very significant proportion of the mural barrier which Horsley ${ }^{86}$ originally suggested measured 39,717 paces.

This revelation is a game-changer that has tremendous ramifications for our understanding of Rome's northwestern frontier, particularly since both were recovered in the extreme west of the Wall with no. 15 from close to the terminus which might feasibly mark the start/end of the mural barrier?

Taken together, the differences in epigraphic practice displayed on these two monumental texts in comparison to all others has great significance, particularly because of their unique reference to the Wall and their alternative method of articulating distance in relation to thousands. This might indicate the same stonemason crafted both examples in a style that differs from artisans carving the other Distance Stones. Alternatively, or perhaps additionally, they could feasibly have been articulated differently because they uniquely refer to the construction of the Wall as opposed to other parts of the frontier infrastructure.

\section{PLACEMENT: AN ALTERNATIVE PROPOSITION}

None of Distance Stones were recovered in-situ, so it is entirely possible that some of the inscriptions refer to the construction or repair of the Military Way ${ }^{87}$ which could explain the duplication of measured distance as later repairs to the same work-sectors. This early hypothesis gained no traction, despite the raising of Roman honorific inscriptions being commonly employed to mark road construction and repair in other contexts ${ }^{88}$. Since the Military Way was a strategically and logistically integral component of the Wall's infrastructure and functionality, it is plausible to suggest the practice of monumental inscriptions are also highly likely to have marked its construction and/or repair.

Graafstal ${ }^{89}$ makes a compelling case for construction of the Military Way in advance of the Wall, most likely as part of the pre-building planning of the infrastructure ${ }^{90}$. Indeed, given the roadway's strategic importance for facilitating deployment of personnel building the mural barrier and policing the region as well as the transportation of livestock and essential supplies ${ }^{91}$, it is here suggested as unlikely that the Wall preceded the Military Way. Macdonald ${ }^{92}$ opened the potential that the "Rampart, Ditch and Military Way had each been assigned to a different set of men", an observation that did not make it into his second edition ${ }^{93}$. Keppie also notes that the structure referred to on the Distance Stones is not described, but that "the passer-by would see from the location of the building-record what had been constructed" 94 . This infers the monumental texts were logically placed in positions of prominence close to the structure to which they refer for maximum impact in terms of significance and content. This is a familiar practice for Roman monumental inscriptions that would traditionally have been placed in

\footnotetext{
6 HORSLEY 1732, 162.

7 HÜBNER 1873, 193.

88 SAUER 2014; BISHOP 2019, 32

89 GRAAFSTAL, forthcoming.

90 STEER 1957, 164; POULTER 2018, 138

91 BISHOP 2019, 20.

2 MACDONALD 1911, 295.

MACDONALD 1934.

KEPPIE 1998, 49.
} 
high traffic areas to engage the widest possible audience thereby validating and reinforcing Roman authority ${ }^{95}$.

Logic dictates then, if they were originally embedded into the Wall, the Distance Stones should have been placed at locations with high footfall such as at crossing points or fort entranceways. Recent research using LiDAR technologies have, however, concluded that their projected locations do not correlate with Roman installations ${ }^{96}$. The proposal for them to have been installed at these locations for convenience rather than at places that accurately record their constructed distance ${ }^{97}$ is valid, though it runs contrary to the Roman penchant for precision in measurements as conveyed by the inscriptions themselves. Instead, perhaps the Distance Stones were carved in anticipation of construction work being undertaken and later updated with accurate distances and installed at appropriate points along the Military Way in line with traditional practice for distance markers where Romans and locals using this easily navigable roadway would have been regularly exposed to them. In this context the sculptures were empowered to fulfil one of their primary functions acting as propogandist tools to promote Rome's authority over the region, demonstrate the military strength of the Legions to enforce that power and to project the Empire's subjugation of indigenous peoples ${ }^{98}$, making them less likely to revolt.

In his attempts to determine whether the distances expressed by the letter ' $P$ ' on the Antonine Wall inscriptions (variously inscribed as PER MIL $P, M P, P P$ or $P$ ) refers to abbreviations of passus or pedes (paces or feet), Horlsey ${ }^{99}$ draws comparisons with milestones terminology millia passuum to conclude Roman miles and paces were intended. Setting aside the validity of Horsley's interpretation and later suggestions for altered terminology as construction of the limes progressed ${ }^{100}$ for the reasons stated above, his comparison to milestones has potential significance that has been overlooked by Macdonald ${ }^{101}$ and others since.

Roman milestones are normally, though not always, associated with the construction or repair of roads ${ }^{102}$. The Military Way lies on average $40 \mathrm{~m}$ to the south of the Antonine Wall and, since it respects the limes, the planning of both structural features can be reasonably expected to have coincided $^{103}$. Long stretches of the Military Way are no longer visible and likely to have been built over, at least through the urban development of Glasgow in the west. However, it has long been known that landowners robbed the stones from the Wall for drystone dykes and other buildings. For example, Wodrow $^{104}$ mentions ample stones available by digging just a foot of earth close to Summerston Farm where no. 6 was discovered. This is supported by Horsley' ${ }^{105}$ assertion for the Wall's foundation stonework being "laid open and dug up for

\footnotetext{
95 MACMULLEN 1982; KOLB 2014, 658; BREEZE/FERRIS 2016, 32; HANNON/ROHL/WILSON 2017, 14

${ }_{96}$ HANNON/ROHL/WILSON 2017, 14.

${ }_{97}$ HANNON/ROHL/WILSON 2017, 14

${ }^{98}$ KEPPIE 1979, 4-5.

99 HORSLEY 1732

100 BATES 1898

101 MACDONALD 1934, 360.

102 SAUER 2014; BISHOP 2019, 46.

103 POULTER 2018.

104 WODROW 1843, 66.

${ }^{105}$ HORSLEY 1732, 163.
}

near a mile together, from the middle of Ferguston Moor east of New Kirkpatrick almost to the village of Summerston". Given that the stones lay under only a foot of earth it is possible that they derive, not from the base of the Wall, but from the kerb stones lining the Military Way. If we can accept this, then no. 6 could have plausibly been recovered from the Military Way since it came from the same context.

Gordon $^{106}$ and Stuart ${ }^{107}$ cast significant light on this by stating the ditch at Ferguston Moor was in a good state of preservation ${ }^{108}$ and the Military Way was also very well preserved with a stretch passing within thirteen paces of the Wall here. Further significance can be ascribed to this location given Macdonald's ${ }^{109}$ comment that no. 7 may also once have stood upon the Military Way based on the stone's recovery c. 100 yards from the Wall, another point excised from his second edition ${ }^{110}$. Steer and Cormack ${ }^{111}$ make the critical observation that nos 9, 10 and 11 (all recording a distance of 3000) must refer to the same sector of work. To this we might add no. 18 which contains an incomplete inscription devoid of distance, but stylistically replicating no. 9 of the $20^{\text {th }}$ Legion. Maxwell ${ }^{112}$ suggests this may be a product of the workshop of the $20^{\text {th }}$ Legion which leads him to concur with Steer and Cormack ${ }^{113}$ for placement of one from each pair on the north and south of the Wall. This would be in line with proposed practice on Hadrian's Wall where commemorative stones are thought to have been set into the inner and outer faces of both vallum mounds ${ }^{114}$ and possibly on the north face of the Wall itself ${ }^{115}$. That assertion is based on fragments from five centurial stones recovered by contractors building a housing estate without experience in archaeological excavation and it is therefore impossible to determine whether they derive from original contexts. Since none of the Distance Stones were recovered from original contexts it is equally possible that these examples constitute the placement of pairings on either side of the Military Way - one facing east and one west at either end of a completed sector. Here, it is important to note that no. 2 has been traditionally assigned to the east of Auchendavy but, based on the inscribed distance of MP III dedicated by the $20^{\text {th }}$ Legion and the absence of any reliable information on its findspot, it may instead have been originally placed in the vicinity of Castlehill.

\section{NEW INSIGHTS AND INTERPRETATIONS}

Close engagement with this unique body of evidence has cast up some additional intriguing patterns or points worthy of note, including:

\section{MAPPING THE MONUMENTS}

Following on from Macdonald's ${ }^{116}$ schematic for placement of the Distance Stones in locations that he
106 GORDON 1726.
107 STUART 1852, 310.
108 at 30' wide and 20' deep.
109 MACDONALD 1911, 299.
110 MACDONALD 1934
111 STEER/CORMACK 1969, 125.
112 MAXWELL 1974, 328.
113 STEER/CORMACK 1969.
114 RICHMOND AND BIRLEY 1937, 227.
115 KEPPIE 1976, 59.
116 MACDONALD 1911; MACDONALD 1934. 


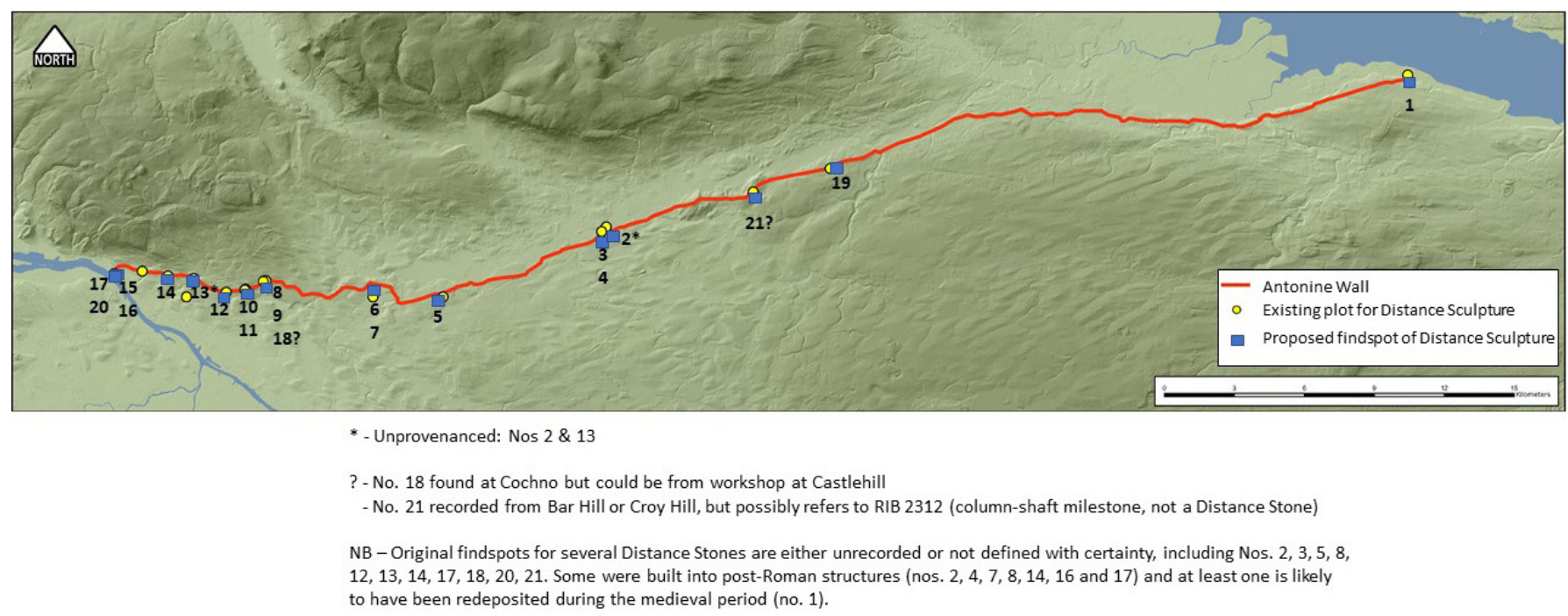

Fig. 7. Proposed locations of the Distance Stones.

extrapolates onto the Wall, a detailed survey of contexts of discovery, where recorded, has thrown up inaccuracies in the mapping of these monuments on both historical maps and digital platforms (see Appendix I). This includes Canmore ${ }^{117}$ where discrepancies from recorded findspots combined with approximate locations have erroneously displaced some. A review of findspots (Table 1 ) presents the opportunity to propose an alternative map for placements with a higher degree of precision and shows that all examples most likely originated from south of the Wall and could plausibly have been placed along the Military Way in line with distance markers associated with other roadways.

\section{IMPERIAL TITLES}

Nos 4 and 13 are the only examples devoid of dedications to the Emperor, though it is evident from the articulation of text on no. 14 that the Imperial dedication was not originally intended for inclusion in that inscription ${ }^{118}$. Macdonald ${ }^{119}$ attributes the omission on no. 13 as accidental. More likely it is because none of these three were originally intended to act as Distance Stones but may have been adapted from commemorative building stones of Legio II (nos 13 and 14) and Legio $X X$ (no. 4) to serve that purpose, see below.

\section{MAKING A MONUMENT AND RE-PURPOSING MONUMENTAL SCULPTURES}

Macdonald asserts the Distance Stones were "all produced about the same time and all destined to serve the same purpose" 120 , but this is by no means certain. A critical review of the inscriptions suggests that some could have originally been destined for a different purpose as indicated by the placement of text and awkward squeezing in at illogical positions between sculpted features on some. For instance, no. 2 is stylistically different from other examples and has been compared to tombstones from the Danube and Britain, e.g. RIB $832^{121}$. The decorative design sculpted onto no. 19 has been likened to an example from a Principia in a

\footnotetext{
117 https://canmore.org.uk/

118 KEPPIE 1998, 85.

119 MACDONALD 1911, 280.

120 MACDONALD 1934, 393.

${ }^{121}$ KEPPIE 1998, 72.
}

Hadrian's Wall fort ${ }^{122}$.

It is equally possible that nos 4,13 and 14 were never intended to be Distance Stones since their original inscriptions do not incorporate dedications to the emperor, the dedication on no. 14 being poorly articulated and squeezed into an area outside of the main inscription panel. Similarly, nos 11 and 17 differ markedly from others in their sculptural style and content. No. 11 potentially depicts Britannia where Victory could normally be expected since the Fig. is devoid of wings ${ }^{123}$ and 17 depicts a reclining Victory. The texts on both are clumsily interspersed through sculpted architectural features, including shield-like panels and façade.

An interesting point of note is the placement of FEC (or an abbreviation to $F$ ) which is omitted or out of place on several stones, including coming at the end of the recorded distances on nos 1 and 12. It is missing entirely from nos 5 and 6 and appears to have been a later addition to no. 9 .

Overall, facets of these examples combine to infer that some Distance Stones may alternatively have been relief-sculpted inscriptions or building commemorations originally intended for a different purpose but re-fashioned and placed on the new northern frontier to mark the making of the monument.

\section{DELIBERATE DEPOSITION}

This detailed survey of the Distance Stones incorporated a review of depositional contexts that casts significant doubt upon the long-established proposal for their deliberate deposition into pits by a departing Roman army $^{124}$. In reality, of the 21 known examples, contexts of discovery for eleven are not recorded ${ }^{125}$, with at least seven having been taken out of original context and subsequently built into later structures ${ }^{126}$.

Of those where findspots are marginally better recorded, no. 1 was originally thought to come from a deliberately dug pit, though later excavation in the immediate environs disputes that, concluding it was subject to medieval

\footnotetext{
122 KEPPIE 1998, 90

123 KEPPIE 1979, 16.

124 MACDONALD 1934, 394; KEPPIE 1976, 60.

$125 \operatorname{nos} 2,3,5,8,12,13,14,17,18,20$ and 21.

$126 \operatorname{nos} 2,4,7,8,14,16$ and 17
} 
re-deposition ${ }^{127}$; no. 4 was reportedly discovered face-down three feet below 'the Roman ditch'; nos 6, 7 and 19 may have been recovered from the vicinity of the Military Way; no. 10 was face-down on the southern slope of a hill 3 foot below the surface; and nos 15 and 16 are recorded as having been ploughed up at the end of the Wall.

Therefore, only nos. 9 and 11 were recovered from contexts where farmhands who found them considered them to be deliberately dug pits. There is a discrepancy in the recorded findspot for no. 9 since Buchanan ${ }^{128}$ first floated the idea of it being thrown into a ditch 3 foot below the surface on the southern slope of Hutcheson Hill and thereafter erroneously recorded on historical Ordnance Survey maps from the berm of the Wall ${ }^{129}$, despite it being reportedly found 'within a few yards south from the fort' ${ }^{\prime} 30$. No. 11 has also been assigned a recovery context from a shallow pit through the opinion of the ploughman who discovered $\mathrm{it}^{131}$. Both examples confirm that farm workers with no experience in excavating archaeological materials or interpreting the stratigraphic relationships of objects and their depositional contexts come under the realms of unreliable sources of pivotal contextual information.

It has been suggested that examples from known findspots were carried only a short distance away from the Wall since their weight made transportation further afield problematic ${ }^{132}$, though they were evidently carried a reasonable distance to be placed in their intended position in the first place. Others, such as no. 6, came from foundation stones commonly ascribed to the Wall, but this research suggests the stones may more plausibly have been recovered from the Military Way (see Appendix I).

\section{WORKSHOPS}

If we can accept that no. 2 of unknown provenance which commemorates a distance of MP III built by the $20^{\text {th }}$ Legion along with nos 9,10 and 11 as well as no. 18 which is incomplete and contains no distance, could have originally derived from Castlehill we may have identified the workshop producing this group of stones. Given the proximity of nos 5-8 to Balmuildy, it is possible that a stonemason's workshop may also have been located there.

\section{FUTURE RESEARCH OPPORTUNITIES}

There is much to be gained from a deeper engagement with inscriptions and other evidence associated with the Antonine Wall. This current research demonstrates the validity of deconstructing long-held interpretations in order to present alternative, if controversial, perspectives on the Roman campaigns in northern Britain and, potentially, other provinces. It is beyond doubt that many more Distance Stones remain undiscovered in the landscape and a targeted programme of GPR exploring potential locations of these lost sculptures should be an absolute priority. Future research agendas should be alert to the possibility that these

\footnotetext{
127 BAILEY/ DEVEREUX 1987

128 BUCHANAN 1883, 18.

129 MACDONALD 1911, 285.

${ }^{130}$ John Buchanan 1871 GUL MR 50/49, no. 2; KEPPIE 1998, 79.

131 STEER/CORMACK 1969, 122

132 KEPPIE 1976, 60.
}

monumental inscriptions were most likely placed south of the Wall so particular attention should be directed to the environs of the Military Way (both north and south of the road). Given the discrepancies in translation of $M P, P P$ and $P$, the potential for placement at regular intervals between 3,000-4,000 feet as well as 18,000-23,000 feet should be considered.

Critically, since recent non-destructive analysis confirms intervention has a detrimental impact on the survival of surface treatments ${ }^{133}$, any future discoveries of monumental inscriptions should not be subjected to intensive cleaning or conservation in advance of a comprehensive programme of analysis to identify and reconstruct original pigments and surface treatments.

\section{CONCLUDING COMMENTS}

A review of the historical, contextual and material evidence associated with the Antonine Wall Distance Stones has cast significant new light onto these unique frontier sculptures. It proposes alternative perspectives and new dimensions to the Distance Stones that strip away past interpretive layers to consider their material and cultural properties for the people who commissioned, carved and engaged with them from the $2^{\text {nd }}$ century through to the present day. Widely accepted hypotheses on their textual translation has thrown up inconsistent practices compared with other Roman distance markers. The complexities historically imposed relating to their incorporation of $M P, P$ $P$ or $P$ continues to permeate scholarship, but this research questions the validity of some traditional approaches and makes alternative suggestions for interpretations.

Past reliance has been placed upon similarities between the inscriptions, but differences have been revealed that cast further doubt upon their traditional interpretation. This includes blanket acceptance that they refer in their entirety to the construction of the Antonine Wall, despite only two explicitly mentioning work on the rampart through the term 'OPUS VALLI'. Seen through the prism of contemporary models, it is perhaps surprising that interpretation of this body of evidence hinges so completely on two examples which in any other context would be considered statistical outliers at less than $10 \%$ of the collection. That their significance as the only example of stones to measure distances in the tens of thousands has escaped the attention of scholarship for centuries is surprising. However, those differences combine to mark them out as special and lends weight to the hypothesis that these two may uniquely refer to the construction of the Antonine Wall. Past references to the potential that some may refer to other parts of the frontier infrastructure have been systematically lost as Macdonald and others have extrapolated distances to fit along proposed work-sectors in attempts to reconstruct the rampart. A full review of depositional contexts further highlights the shaky foundations upon which some of our historical hypothesis have been built. It has, for example, been widely accepted that the Distance Stones were buried in pits by a departing Roman army ${ }^{134}$, but the reliability of recorded discovery contexts is tenuous at best.

Taken together, significant historical inaccuracies have
33 CAMPBELL 2020.
134 MACDONALD 1934, 394; KEPPIE 1976, 60. 
evidently combined to influence traditional interpretations of the Distance Stones and the structure/s to which they refer have not been holistically considered. Some finds locations have been inaccurately recorded in both published accounts and modern digital platforms which, on the surface, point to placement of some to the north of the Wall. In reality, there is no evidence that they were originally located anywhere but to the south of the Wall and the distances involved combine with some recorded contexts of discovery to suggest that they might reasonably, and logically, have been alternatively placed along the Military Way consistent with Roman practice for other markers of distance.

\section{ACKNOWLEDGEMENTS}

Most sincere thanks are due to Professors Lawrence Keppie, Bill Hanson, Martin Millett and Eberhard Sauer and to John Poulter for reading and commenting on an early version of this paper. Their insightful comments have helped greatly in refining the finished paper, though responsibility for all errors and/or controversial aspects rests entirely with the author.

\section{FUNDING INFORMATION}

This work was supported by grants from Historic Environment Scotland (Grant Number HEAP2470491033) and the University of Glasgow's Lord Kelvin Adam Smith (LKAS) Leadership Fellowship. The author declares that they have no conflict of interest. The author is enormously grateful to both institutions for funding ongoing research on ancient statuary through the Paints and Pigments In the Past (PPIP) project.

\section{REFERENCES}

ANDERSON 1771

Anderson, J., Of the Roman Wall between the Forth \& Clyde; and of some Discoveries which have lately been made upon it (Glasgow: Andersonian Library, University of Strathclyde).

BAILEY/DEVEREUX 1987

Bailey, G. B./Devereux, D. F., The eastern terminus of the Antonine Wall: a review, Proceedings of the Society of Antiquaries of Scotland 117, 93-104.

BATES 1898

Bates, C., The Distance-Slabs of the Antonine Wall and the Roman names of its fortresses, Archaeologia Aeliana 19, 105-114.

BISHOP 2019

Bishop, M.C., The secret history of the Roman Roads of Britain (Barnsley: Pen and Sword Books).

\section{BREEZE 1990}

Breeze, D. J., The flag of Legion II Augusta on the Bridgeness distance slab, Proceedings of the Society of Antiquaries of Scotland 119, 133-142.

BREEZE 2006

Breeze, D. J., The Antonine Wall (Edinburgh: Birlinn).

BREEZE/FERRIS 2016

Breeze, D. J./Ferris, I,. They think it's all over: The face of victory on the British frontier, Journal of Conflict Archaeology 1, 19-39.

\section{BRUUN/EDMONDSON 2014}

Bruun, C./Edmondson, J. (eds), The Oxford Handbook of Roman Epigraphy (Oxford: Oxford University Press).

BUCHANAN 1883

Buchanan, J., Recent discovery of a Roman inscription near
Glasgow, Transactions of Glasgow Archaeological Society 2, 11-28.

CADELL 1871

Cadell, H., Note of a sculptured Roman slab recently discovered on the estate of Grange, Linlithgowshire, and presented to the Museum, Proceedings of the Society of Antiquaries of Scotland 8, 109-114.

\section{CAMDEN 1607}

Camden, W., Britannia (London).

\section{CAMDEN 1722}

Camden, W., Britannia: or a chorographical description of Great Britain and Ireland, together with the adjacent Islands. Written in Latin by William Camden: and translated into English, with additions and improvements. Revised with large additions, by Edmund Gibson (London: Printed for W. Bowyer, W. Whiston, T. Davies, W. Strahan, J. and F. Rivington [and 22 others in London]).

\section{CAMPBELL 2020}

Campbell, L., Polychromy on the Antonine Wall Distance sculptures: non-destructive Identification of pigments on Roman reliefs, Britannia.

\section{CLOSE-BROOKS 1982}

Close-Brooks, J., The Bridgeness distance slab, Proceedings of the Society of Antiquaries of Scotland 111, 519-521.

COLLINGWOOD/WRIGHT 1965

Collingwood R. G./Wright, R. P., The Roman Inscriptions of Britain, Vol. 1. Oxford: Clarendon Press. Available online at https://romaninscriptionsofbritain.org/ (last viewed 20 ${ }^{\text {th }}$ February 2020).

\section{DOORYH et alli 2005}

Dooryh, E./Anne M./Bard, I./Hodeau J. L./Martinetto, P./ Rondot, S./Salomon, J./Vaughan, G. B. M. and Walter, P., Non-destructive synchrotron X-ray diffraction mapping of a Roman painting, Applied Physics A 81, 663-667.

\section{FERRIS 2000}

Ferris, I. M., Enemies of Rome: barbarians through Roman eyes (Stroud: Sutton Publishing).

FORTUNATO/RITTER/FABIAN 2005

Fortunato, G./Ritter, A./Fabian, D., Old Masters' lead white pigments: investigations of paintings from the 16 th to the 17th century using high precision lead isotope abundance ratios, Analyst 130, 898-906

\section{GIBB 1902}

Gibb, A., New Measurement of the Vallum of Antoninus Pius, Northern Notes and Queries 16 (Jan 1902), No. 63, 117-126.

\section{GLASGOW ARCHAEOLOGICAL SOCIETY 1899}

Glasgow Archaeological Society, The Antonine Wall report: being an account of excavations, etc., made under the direction of the Glasgow Archaeological Society during 1890-93 (Glasgow: James Maclehose and Sons).

\section{GORDON 1726}

Gordon, A., Itinerarium Septentrionale (London: Printed for the author and sold by G. Strahan, J. Woodman, W and J. Innys and T. Woodward).

GRAAFSTAL, forthcoming

Graafstal, E., Wing Walls and Waterworks. On the planning and purpose of the Antonine Wall.

\section{GREWE 2013}

Grewe, K., Streckenmessung im antiken Aquädukt- und Straßenbau. In: Fischer/T. Horn, H.G. (eds), Straßen von der Frühgeschichte bis in die Moderne. VerkehrswegeKulturträger - Lebensraum. Akten des Interdisziplinären Kolloquiums Köln, Februar 2011 (Wiesbaden), 1-23.

HAMILTON 1933

Hamilton, G., The House of Hamiltons (Edinburgh: Printed by J. Skinner \& Co.). 
HANNON/ROHL/WILSON 2017

Hannon, N./Rohl, D. J./Wilson, L., The Antonine Wall's Distance Slabs: LiDAR as metric survey, Journal of Roman Archaeology 30/1, 447-468.

HANSON/MAXWELL 1983

Hanson, W. S./Maxwell, G.S., Rome's north west frontier: The Antonine Wall (Edinburgh: Edinburgh University Press).

HASSALL 1977

Hassall, M. W. C., Wingless Victories. In: Munby, J./ Henig, M. (eds), Roman Life and Art in Britain. A celebration in honour of eightieth birthday of Jocelyn Toynbee. British Archaeological Reports 41 (Oxford).

HASSALL 1983

Hassall, M. W. C., The Building of the Antonine Wall, Britannia 14, 262-264.

HODGSON 1840

Hodgson, J., History of Northumberland, part II, vol. 3 (Newcastle).

HORSLEY 1732

Horsley, J., Britannia Romana or the Roman antiquities of Britain (London: John Osborn and Thomas Longman).

HÜBNER 1873

Hübner, E., CIL VII, Inscriptiones Britanniae Latinae

KEPPIE 1974

Keppie, L. J. F., The building of the Antonine Wall: archaeological and epigraphic evidence, Proceedings of the Society of Antiquaries of Scotland, 105, 151-165.

KEPPIE 1976

Keppie, L. J. F., The distance slabs from the Antonine Wall: some problems, Scottish Archaeological Forum 7, 57-66.

KEPPIE 1979

Keppie L. J. F., Roman Distance Slabs from the Antonine Wall: A brief guide (Glasgow: Hunterian Museum).

KEPPIE 1998

Keppie L. J. F., Roman inscribed and sculptured stones in the Hunterian Museum, University of Glasgow (London: Society for the Promotion of Roman Studies).

KEPPIE 2012

Keppie L. J. F., The Antiquarian Rediscovery of the Antonine KOLB 2014 Wall (Edinburgh: Society of Antiquaries of Scotland).

Kolb, A., Communications and Mobility in the Roman Empire. In: Bruun, C./Edmondson, J. (eds), Oxford Handbook of Roman Epigraphy (Oxford: Oxford University Press), 649-670.

KOLB 2019

Kolb A., Via ducta - Roman Road Building: An Introduction to Its Significance, the Sources and the State of Research. In: Kolb, A. (ed.) Roman Roads: New Evidence - New Perspectives (Berlin: De Gruyter), 3-21.

MACDONALD 1911

Macdonald, G., The Roman Wall in Scotland (Glasgow: James Maclehose and Sons).

MACDONALD 1934

Macdonald, G., The Roman Wall in Scotland, Second Edition (Oxford: Clarendon Press).

MACDONALD 1897

Macdonald, J., Tituli Hunteriani: An account of the Roman stones in the Hunterian Museum (Glasgow: Annan and Sons).

MACFARLANE 1908

Macfarlane, W., Geographical Collections, Vol 3 [Scottish Historical Society volume 53] (Edinburgh).

MACMULLEN 1982

Macmullen, R., The Epigraphic Habit in the Roman Empire, American Journal of Philology 103(3). 233-246.

MAITLAND 1757
Maitland, W., The history and antiquities of Scotland, from the earliest account of time to the death of James the First, anno 1437 (London).

MAXWELL 1974

Maxwell, G., The building of the Antonine wall. In: Pippidi, D. M. (ed.), Actes du IXe Congress International d'Etudes sur les Frontieres Romaines (Bucuresti: Editura Academiei), 327332.

MONUMENTA ROMANI IMPERII 1768

Monumenta Romani imperii, in Scotia, maxime vero inter vestigia valli, auspiciis Antonini Pii Imperatoris, a Fortha usque ad Glottam perducti, reperta, et in Academia Glasguensi adservata, iconibus expressa (Glasgow: University of Glasgow).

\section{PHILLIPS 1972}

Phillips E. P., The Roman distance slab from Bridgeness, Proceedings of the Society of Antiquaries of Scotland 105, 176182.

POULTER 2018

Poulter, J., New Discoveries Relating to the Planning of the Antonine Wall in Scotland, Britannia 49, 113-146.

RICHMOND/BIRLEY 1937

Richmond, I. A./Birley, E., Centurial stones from the vallum west of Denton Burn, Archaeologia Aeliana 4(14), 227-242.

ROBERTSON 2015

Robertson, A. S., The Antonine Wall. A handbook to Scotland's Roman frontier (6th edition revised and edited by L.J.F. Keppie) (Glasgow: Glasgow Archaeological Society).

SAGAN 1997

Sagan, C., The Demon-Haunted World: Science as a Candle in the Dark (1st ed.) (New York: Ballantine).

\section{SAUER 2014}

Sauer, E. W. Milestones and Instability (Mid Third to Early Fourth Centuries AD), Ancient Society 44. 257-305.

SCALIGER 1606

Scaliger, J. J., Thesaurus Temporum Eusebii Pamphili (Leiden: Lugduni Batavorum excudebat Thomas Basson sumptibus Commelinorum).

SIBBALD 1707

Sibbald, R., Historical Enquiries (Edinburgh).

STEER 1957

Steer, K. A., The Nature and Purpose of the Expansions of the Antonine Wall, Proceedings of the Society of Antiquaries of Scotland 90, 161-169.

STEER/CORMACK 1971

Steer K. A./Cormack, E. A., A new distance-slab from the Antonine Wall, Proceedings of the Society of Antiquaries of Scotland 101, 122-126.

STRANG 2007

Strang, A., The Distance Slabs of the Antonine Wall (and deduction of their most likely disposition) (Nottingham: Alastair Strang).

STUART 1852

Stuart, R., Caledonia Romana: A descriptive account of the Roman antiquities of Scotland (Edinburgh: Sutherland and Knox).

STUKELEY 1720

Stukeley, W., An Account of a Roman Temple and other Antiquities near Graham's Dyke in Scotland (London).

WODROW 1843

Wodrow, R., Analecta, or Materials for a History of Remarkable Providence (Maitland Club no. 60), volume 4 (Edinburgh).

WOOLF 1996

Woolf, G., Monumental Writing and the Expansion of Roman Society in the Early Empire. Journal of Roman Studies 86, 22-39. 


\section{APPENDIX I}

\section{1: Bridgeness (National Museum of Scotland Number X.FV 27, RIB 2139)}

IMP CAES TITO AELIO HADRI ANTONINO AVG PIO $P$ P $P$ LEG II AVG PER $M$ P $P$ IIIIDCL II FEC (For the Emperor Caesar Titus Aelius Hadrianus Antoninus Augustus Pius, Father of his country, the Second Augustan Legion built this over a distance of 4652)

Carved from buff sandstone, this is the largest known Distance Stone. It was found in 1868 and donated to the National Museum of Antiquities of Scotland (now National Museum of Scotland). An inscribed central panel is flanked on either side by peltae with griffin head terminals. The left panel depicts a cavalryman on horseback galloping down a group of four naked indigenous warriors in the midst of battle as he prepares to cast a spear at them. One warrior is prostate on his back, another has either a pilum ${ }^{135}$ or broken off portion of the leg from the fallen warrior behind protruding from his back ${ }^{136}$, a third is decapitated and a fourth strikes a contemplative pose. The right panel depicts a religious scene thought to represent the suovetaurilia ${ }^{137}$ with members of the $2^{\text {nd }}$ Augustan ${ }^{138}$ offering sacrifices and libations on altars below a temple pediment.

This example is comparable in structure, content and composition to the Summerston Farm sculpture (no. 6) and the left panel is similar in composition and structure, if not content, since the Summerston Farm iconography depicts captive naked northerners after battle. Evidence of red colouring on the sculptural reliefs of no. 1 has been noted during episodic cleaning ${ }^{139}$ and recent non-destructive analysis using portable X-Ray Flourescence (pXRF) and Raman Spectroscopy confirmed this brutal scene of battle was originally brought vividly to life in polychrome with a palette of pigments dominated by reds, yellows and whites ${ }^{140}$. The use of bright red minimum (red lead) to depict blood on the decapitated head and neck of one of the fallen warriors is also evident on the Summerston Farm sculpture. Interestingly, this is the only example that inserts FEC after the other text, other examples that contain a reference to FEC (made/built) precede the measured distances either in full or abbreviated only to $\mathrm{F}$.

This monumental inscription was previously thought to mark the eastern terminus of the Wall ${ }^{141}$, though more recent work proposes Carriden as a more plausible candidate for the terminal ${ }^{142}$. The sculpture was recovered from a rocky promontory just above a harbour at Bridgeness belonging to the finder, Mr Henry Cadell of Grange, who considered it to have been deliberately placed there by departing Romans ${ }^{143}$, this too was questioned by Bailey and Devereux who posit a post-Roman re-burial ${ }^{144}$ based on trenching close to the findspot where $14^{\text {th }}-16^{\text {th }}$ Century pottery was recovered from the tumble of the retaining wall. This, coupled with plough-marks on the rear which could not have been the result of ploughing in situ on a rocky promontory, suggest the stone was found out of its original context ${ }^{145}$. The roughly dressed stones recovered directly below and immediately behind the inscription might alternatively indicate a structure into which the monument was embedded as confirmed by crampholes that are also present on other examples. After its donation to the museum a commemorative plaque was placed at the roadside to mark the approximate findspot at NGR NT 01378151.

\section{Unknown Provenance (Hunterian Museum Number GLAHM.F.1, RIB 2173)}

IMP CAESARI T AELIO HADRIANO ANTONINO AVG PIO P P VEXILLATIO LEG XX VAL VIC F PER MIL P III (for the Emperor Caesar Titus Aelius Hadrianus Antoninus Augustus Pius, Father of his Country, a detachment of the Twentieth Valerian and Victorious Legion built this over a distance of 3000)

Carved from buff sandstone, this Distance Stone has an intriguing biography. Its date of recovery is unknown, though recorded by Camden ${ }^{146}$ as being installed into the porch or portico then ballroom or gallery of Dunnottar Castle, Stonehaven, by the $5^{\text {th }}$ Earl Marischal. It was then moved to Marischal College in Aberdeen in 1723 before the Earl donated it to Glasgow College (now University of Glasgow) on his return to Scotland in 1761 after a period of exile for alleged Jacobite sympathies ${ }^{147}$. Keppie's observation that this example differs markedly from others commemorated by detachments of the $20^{\text {th }}$ Legion is significant since he recognises it may derive from a different season of construction or a different sculptural style. He compares it stylistically to tombstones elsewhere in the Empire, including on the Danube and Britain ${ }^{148}$. It contains a central panel framed with triple ribbed border on all 4 sides with swirling decorative bands of ivy tendrils above and below and flanked by elongated peltae depicting plumage of the griffins forming the terminals of each. Two crampholes dovetail at the top ${ }^{149}$, in common with no. 3 .

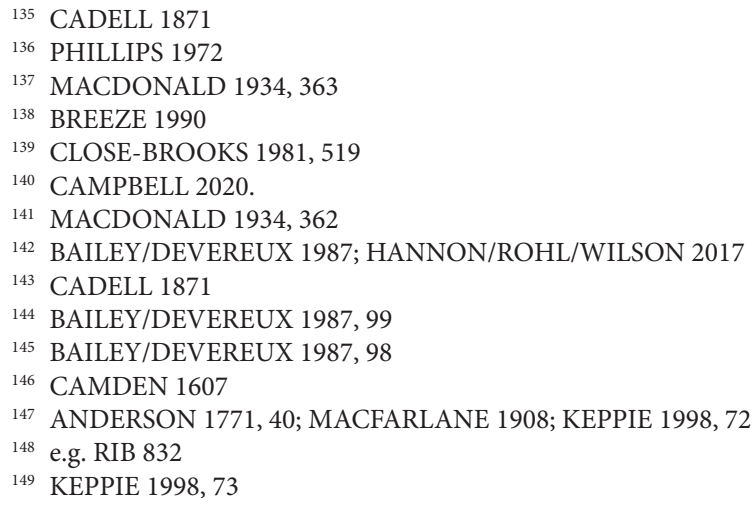


Curiously, Macdonald ${ }^{150}$ fails to record the polychromy on this stone (Fig. 8). This is despite mentioning the Distance Stones were likely to have been "brightly, if crudely, coloured... no vestige of anything of the sort is visible on them now" 151 and despite Camden's ${ }^{152}$ explicit mention of this particular example being gilded under the direction of the $10^{\text {th }}$ Earl Marischal and Horsley $^{153}$ noting black paint. Anderson ${ }^{154}$ makes clear the painting was not the work of university staff, while Gibb confirms the paint was "very properly washed off" ${ }^{155}$ before traces became once more visible during cleaning in $1976^{156}$. My recent pXRF analysis of this monumental inscription confirms the light and dark brown paint was applied during the $17^{\text {th }}$ century given its elemental composition, particularly the very high lead content which is consistent with that period ${ }^{157}$ as opposed to Roman brown pigments which are often dominated by haematite or goethite ${ }^{158}$. The presence of gold gilding can also be confidently assigned a $17^{\text {th }}$ century date since it overlies the brown paint.

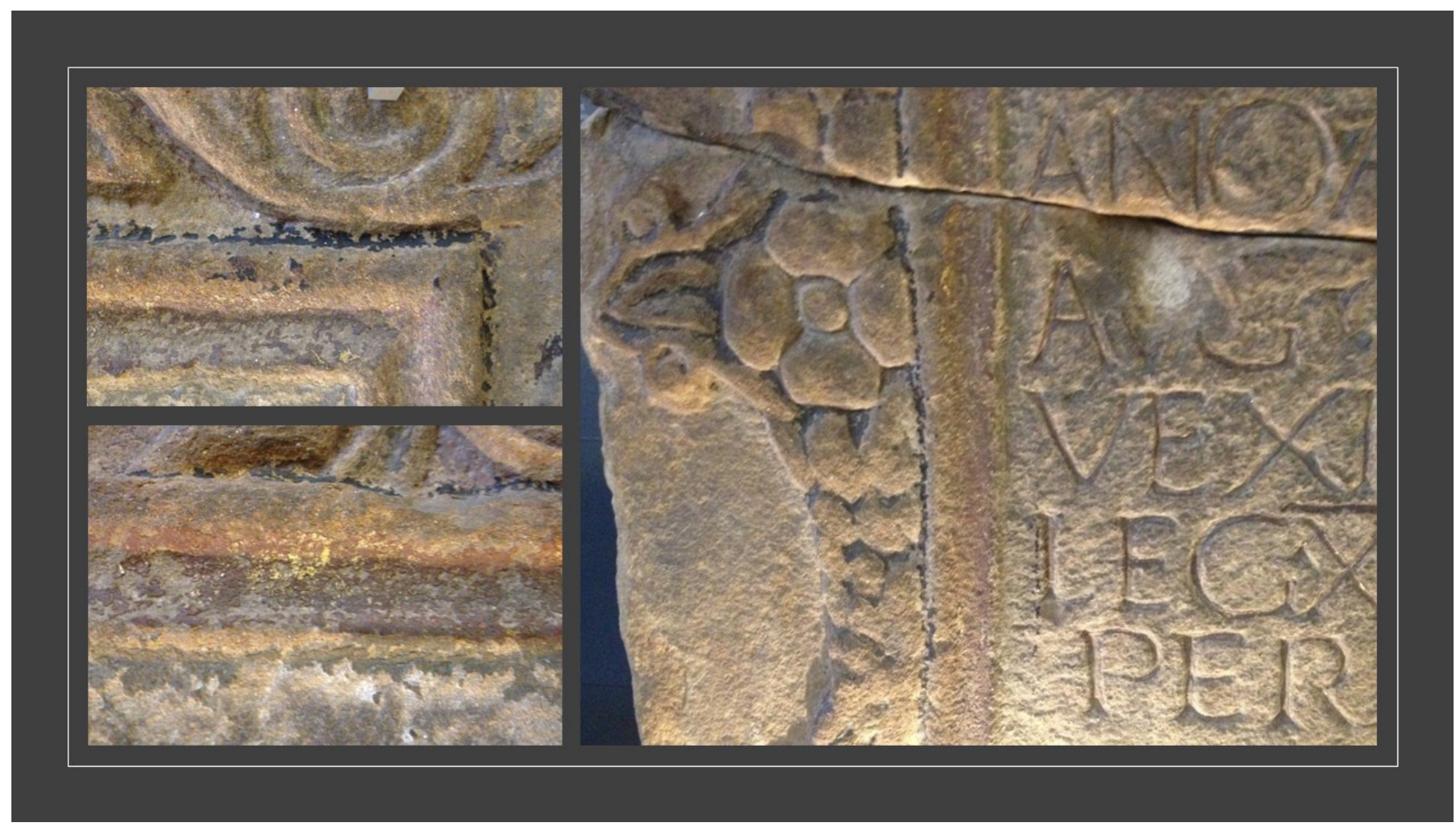

Fig. 8. Polychromy on Distance Stone No. 9 (RIB 2173)

Frustratingly, its findspot and context of discovery is unrecorded except for a note that it was "dug up from the Ruins of this wall [Antonine] and made a present long ago to the ancestors of the late Earl"159. Although Macdonald ${ }^{160}$ arbitrarily places it east of Auchendavy at NGR NS 677 749, Keppie ${ }^{161}$ assigns it more generally to somewhere in the central sector where the construction sequences are less well recorded. In any event, taking the historical evidence at face value, its placement would be east of the Roman fort at Auchendavy ${ }^{162}$ which can be ascribed to south of the Wall given the mural barrier's altered trajectory to a sharp north-easterly direction immediately thereafter (Fig. 9). Indeed, it is entirely possible that this stone pairs with one of the three others recovered close to Bearsden that were also dedicated by detachments of the $20^{\text {th }}$ Legion recording a distance of 3000 feet (not paces). Canmore records it from c. NGR NS 67 75, erroneously placing it north of the wall in the grounds of Bridgend Farm.

\section{Eastermains (Hunterian Museum Number GLAHM.F.2, RIB 2185)}

IMP CAESARI T AELIO HADRIANO ANTONINO AVG PIO $P$ P VEXILLA LEG VI VIC $P$ F $P E R \quad M \quad P$ (For the Emperor Caesar Titus Aelius Hadrianus Antoninus Augustus Pius, Father of his Country, a detachment of the Sixth

\footnotetext{
150 MACDONALD 1934

151 MACDONALD 1911, 310

152 CAMDEN 1607, 711-12

153 HORSLEY 1732, 204

154 ANDERSON 1771, 40

155 GIBB 1902, 80

156 KEPPIE 1998, 73

157 FORTUNATO/RITTER/FABIAN 2005

${ }_{158} \mathrm{DOORYH} /$ et alii 2005; CAMPBELL, in press

159 GORDON 1726, 62

160 MACDONALD1934, 365

161 KEPPIE 1998, 72

${ }^{162}$ MACDONALD 1934, 381
} 
Victorious, Loyal and Faithful Legion built this over a distance of...)

Carved from gritty buff sandstone, this Distance Stone was discovered c. 1740 and purchased by the University in 1744. It finds stylistic and textual parallels with others from the $6^{\text {th }}$ Legion (nos. 7 and 8 ). The differences between these examples are slight (see Fig. 6), but they broadly conform to a central panel with inscribed text dedicated by a 'vexilla' or 'vexillato' (no. 8) of the $6^{\text {th }}$ Legion, framed by plain mouldings, triple ribbed at the top and bottom, and flanked by peltae which, on this stone, have griffin head terminals. Like no. 2, there are two dovetail crampholes in the top ${ }^{163}$. Critically, in common with no. 18 , the inscription has a blank space where the distance of measured units is present on all other Distance Stones. Although Macdonald ${ }^{164}$ proposes it represents a distance of 1000 paces ( 1 Roman mile), his hypothesis is based on conjecture and a series of mathematical leaps in order for it to fit his narrative for proposed measurements between other Distance Stones. Recent non-destructive analysis using Raman spectroscopy suggests the presence of realgar red pigment in some of the letters and the rosette $e^{165}$.

The provenance of this Distance Stone is uncertain, though its recorded discovery was half a mile east of Kirkintilloch fort ${ }^{166}$ and west of Inchbelly Bridge c. $1740^{167}$. Keppie ${ }^{168}$ centres this to a findspot at NGR NS 667747 on the Wall, though Canmore records an approximate findspot of NGR NS 668748 inside the Forth and Clyde Canal just to the north of the Wall. These locations are rather arbitrarily defined, there is nothing in the records to suggest this inscription was recovered from north of the Wall. Though it may well have been placed close to No. 4 at NGR NS 6684174772 it is purely conjecture that this is due to it "commemorating the completion of adjacent lengths by different sets of soldiers" 169 since this stone is devoid of measurement.

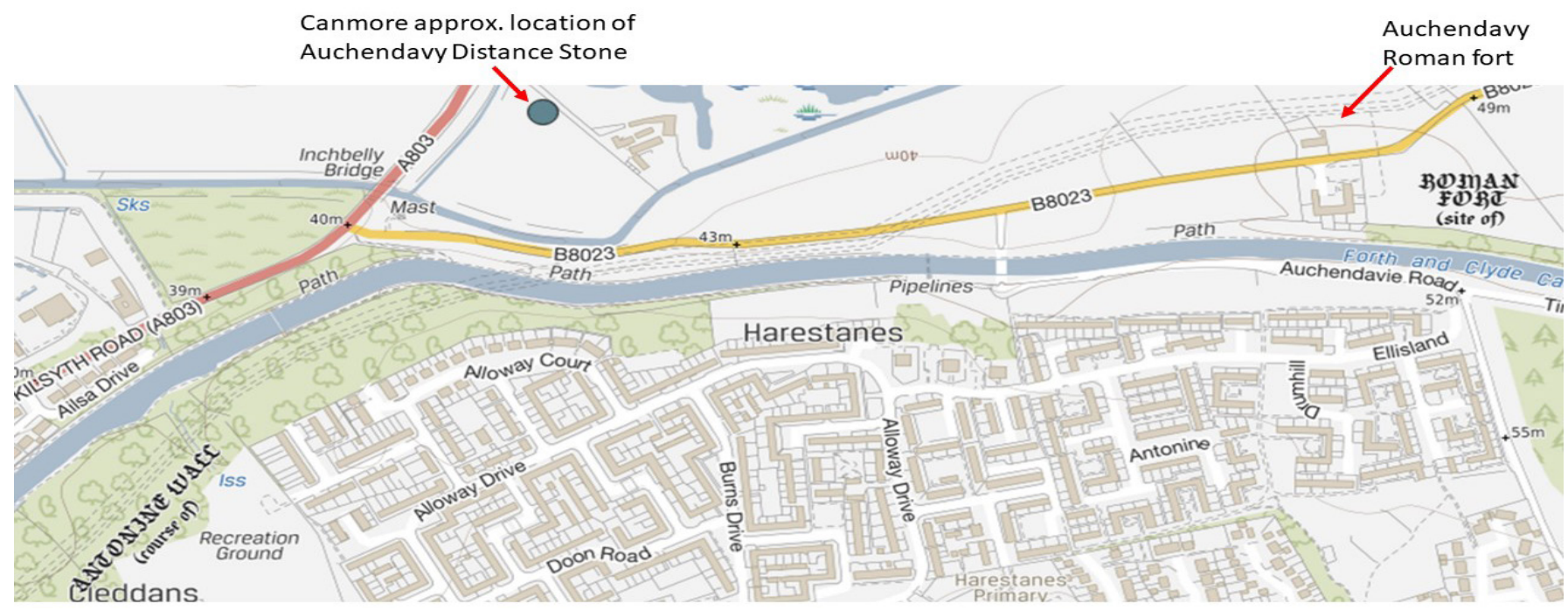

Fig. 9. Map with erroneous findspot on Canmore of Distance Stone No. $2^{170}$

\section{Eastermains (Hunterian Museum Number GLAHM.F3, RIB 2184)}

\section{LEG XX V V FEC M P III P IIICCCIV}

(The Twentieth Valerian and Victorious Legion built this over a distance of 3000 (additional measurement is also included of 3304, possibly erroneously)

Carved from buff sandstone, this Distance Stone was found in 1789 and donated to the University by John Buchanan in 1871. It is the smallest of all those recovered and contains the most basic of information. But that does not detract from the enigma and significance of this artefact. The first part of the text is contained within a trapezoidal ansae panel, below this the distance is inscribed on the left with the legionary emblem of a boar running towards a tree on the right in a scene reminiscent of no. 10 in reverse.

This inscription is devoid of dedication to the emperor, in common with only one other (no. 13). Of all those commemorated by the $20^{\text {th }}$ Legion this, uniquely, does not specify a detachment, prompting Macdonald ${ }^{171}$ to surmise this is because of restricted space available due to the large size of inscribed lettering. It could, alternatively, suggest the $20^{\text {th }}$ were working at full complement at some stage of construction, perhaps the initial stage. Also unique to this inscription is an extensively long measurement, thought to incorporate both paces and feet (3000 paces and 3304 feet) which combine to

\footnotetext{
163 KEPPIE 1998, 74

164 MACDONALD1934, 381

165 CAMPBELL 2020.

166 unknown author, recorded in KEPPIE 1998, 74

167 MAITLAND 1757

168 KEPPIE 1998, 74

169 MACDONALD 1934, 367

170 (C) CANMORE at $100 \mathrm{~m}$

${ }^{171}$ MACDONALD 1934, 368
} 
make $36604 / 5$ paces $^{172}$, very close to the oddly specific measurement of 3666 1/2 ${ }^{173}$ inscribed onto four Distance Stones (nos. 5-8). This hypothesis requires a complex series of cognitive and arithmetical acrobatics that not only defeats the fundamental purpose of the Distance Stones, but it is uncharacteristic of Roman practice. More plausible is Hübner's ${ }^{174}$ early explanation that the stone carver has inadvertent repeated the P III distance along with the other measurements (CCC IV) at a time after the stone was originally carved.

The findspot for this Distance Stone is not recorded with precision, though it was reportedly discovered lying facedown in the Roman ditch through deep ploughing ${ }^{175}$ and later installed into a pigsty near Kirkintilloch ${ }^{176}$, which explains its poor condition. It has been assigned the same findspot as no. 3 at c. NGR NS 667747 on the Wall by Keppie ${ }^{177}$ which differs from that allocated by Canmore in the middle of the canal. Given that it was discovered at a point where the Wall traverses Eastermains c. three quarters of a mile east of Kirkintilloch ${ }^{178}$ and immediately adjoining Whitehill "on the south bank of the canal"179, its findspot is more likely closer to NGR NS 6684174772.

\section{Cawder House, Bishopbriggs (Hunterian Museum Number GLAHM.F.4, RIB 2186)}

IMP CAES TITO AELIO HADRINO ANTONINO AVG PIO $P$ P (For the Emperor Caesar Titus Aelius Hadrianus Antoninus Augustus Pius, Father of his Country, the Second Augustan Legion built this over a distance of $3666_{1 / 2}^{1 / 2}$

Carved from buff sandstone, this inscription is set within plain mouldings flanked on the left with an ansa with central rosette. While it is possible the right ansa has been broken off, Keppie ${ }^{180}$ favours an additional stone block completing the schematic since all edges have been finished in a similar fashion. Two broad shallow dovetail crampholes have been carved in the top. This is one of four examples containing an oddly specific distance of $3666 \frac{1}{2}$ units of measure ${ }^{181}$ that could be pairings originally located at either end of a completed sector ${ }^{182}$, see above for further discussion on this.

Its date of discovery is unknown, though it was recorded as having been incorporated into the walls of Cawder House then into its square keep at the beginning of the $17^{\text {th }}$ century ${ }^{183}$ before being donated to the University c. 1735 by the owner of Cawder House, Mr Stirling of Kier. Earlier accounts of it having been recovered from close to the house at the Wall's ruins

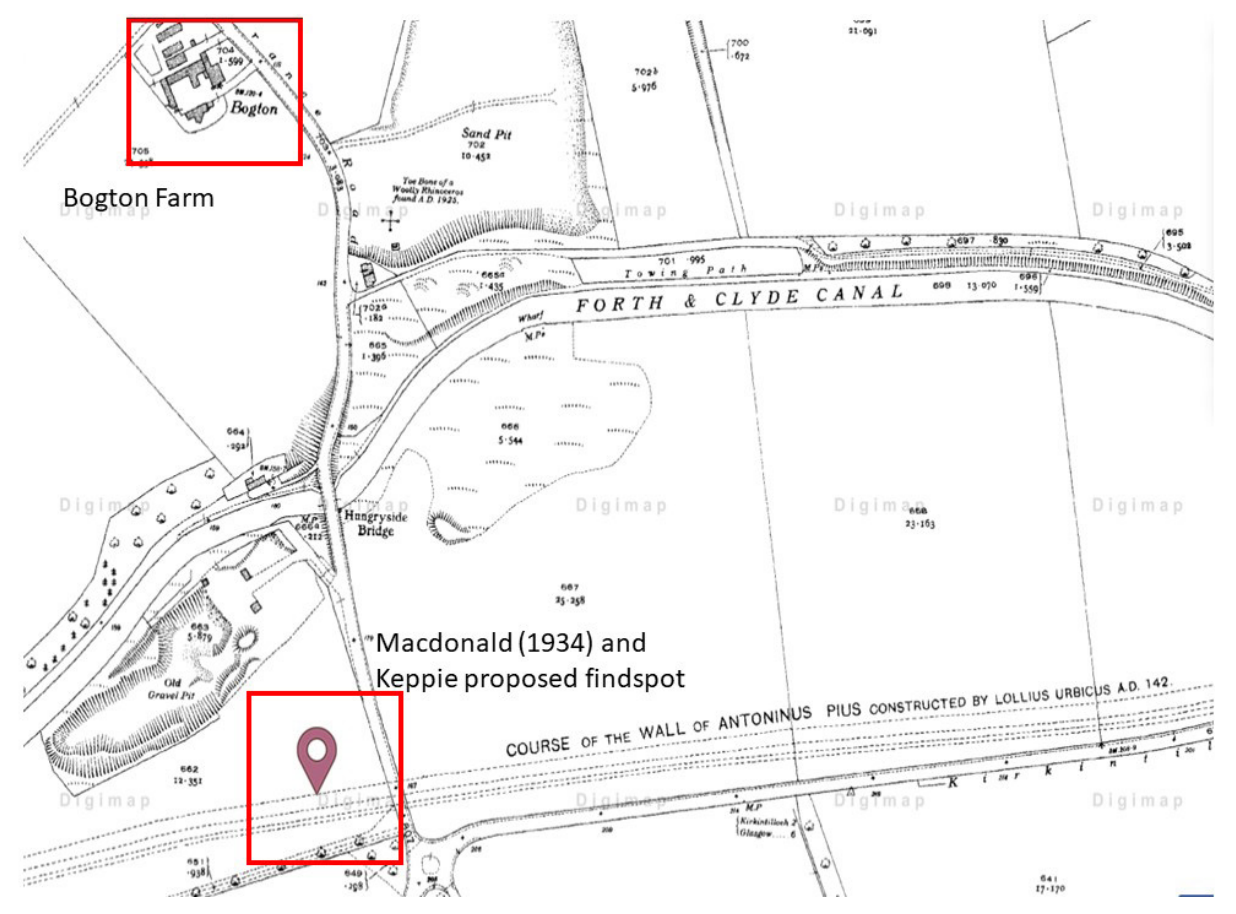

Fig. 10a. Ordnance Survey map (1940s) ${ }^{184}$ with findspot at NGR NS 623728 for no. $5^{185}$

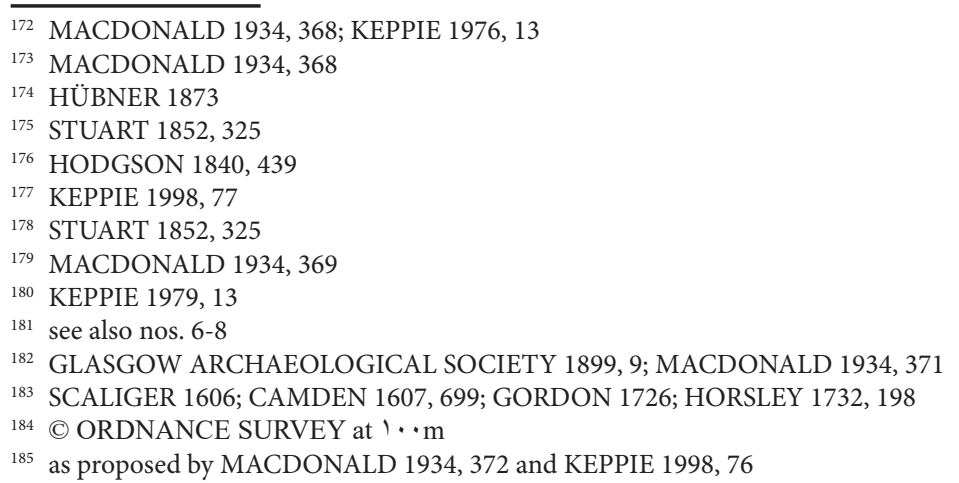


near Balmuildy, the estate upon which Cawder House sits ${ }^{186}$ may instead refer to another inscribed stone of the $2^{\text {nd }}$ Legion from Cawder House, RIB 2209 ${ }^{187}$. Macdonald ${ }^{188}$ is dismissive of Sibbald's proposal and assigns it to Bogton Farm, but this is conjecture based primarily on the inscribed distance (3666 1/2 feet) which aligns with the other examples from this vicinity c. NGR NS $623728^{189}$. Bogton Farm is, however, a good distance north of the Wall (Fig. 10a) and closer to Cadder fort. Despite including Macdonald's proposal for this stone's original place of discovery from Bogton Farm, Canmore has placed its findspot at c. NGR NS 60 72, Wilderness plantation to the south of the Wall and east of Balmuildy (Fig. 10b) which may better reflect its discovery location given its placement between Balmuildy and Cawder House, though it may have been more accurately closer to the Wall and fortlet here at NGR NS 5980372120.

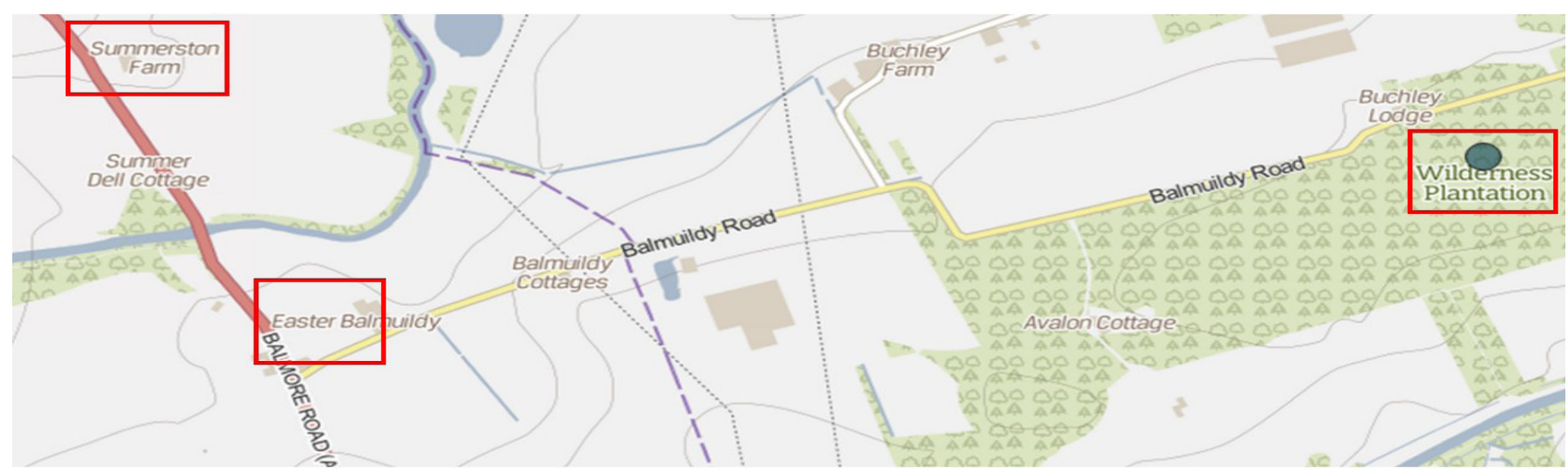

Fig. 10b. Map with no. 5 close to Balmuildy as located by Canmore ${ }^{190}$

\section{Summerston Farm (Hunterian Museum Reference GLAHM.F.5, RIB 2193)}

IMP CAES TITO AELIO HADRIANO ANTONINO AVG PIO $P$ P LEG II AVG PEP [R] $M$ P $P$ III DCLXVIS (For the Emperor Caesar Titus Aelius Hadrianus Antoninus Augustus Pius, Father of his Country, the Second Augustan Legion built this over a distance of $3666_{1 / 2}^{1 / 2}$

Carved from buff sandstone, this sculpted inscription was gifted to the University of Glasgow in 1694 by John Graham of Dougalston. The inscription mirrors the text on no. 5, including the oddly specific measurement of $36661 / 2$ which is thought to refer to construction between Balmuildy and Bogton, adjacent to no. $7^{191}$. The sculpture loosely parallels Bridgeness (no. 1) in structure and composition, though the left panel shows a winged Victory holding a laurel wreath to crown a horseman guarding two bound and naked northern warriors after battle. On the right Rome's eagle perches on the back of the $2^{\text {nd }}$ Legion's emblem, a Capricorn, above another naked captive. Large crampholes have been carved into the sides as well as a small one at the centre of the top.

During cleaning some red pigment became visible ${ }^{192}$ which $\mathrm{pXRF}$ and Raman Spectroscopy has confirmed to be red lead (minium) on the chest, head, beard, thigh and cheek of the captive warriors as well as on the eagle's beak ${ }^{193}$. This bright red pigment may represent blood on the captives here as well as the decapitated head and neck of one of the Bridgeness warriors, while its presence on the eagle's beak could symbolise Rome feasting off the blood of her enemies.

The findspot for this sculpture is uncertain. Despite Gordon ${ }^{194}$ and Horsley ${ }^{195}$ recording its recovery from Castlehill, Macdonald ${ }^{196}$ suggests their proposal is based on erroneous information leading to confusion since Gordon may have been referring to no. 8. Instead, he favours Summerston Farm from the descriptive account of Wodrow ${ }^{197}$ which refers to its recovery from foundation stones dug up for almost one mile between Kilpatrick and Kirkintilloch stretching almost to the village of Summerston to make dyke stone walls ${ }^{198}$. It is quite possible these 'foundation stones' could conceivably derive from kerb stones of the Military Way. Keppie ${ }^{199}$ places it at c. NGR NS 574725 on the Wall, very close to Summerston Farm, but this is significantly north of the mapped location on Canmore (Fig. 11). More likely it was located just to the south of the Wall in the vicinity of the Roman camp c. NGR NS 57427245.

\footnotetext{
186 SIBBALD 1707, 50; GORDON 1726, 54

187 KEPPIE 1998, 76

188 MACDONALD 1934, 371

189 KEPPIE 1998, 76

190 C CANMORE at $200 \mathrm{~m}$

191 KEPPIE 1998, 78

192 KEPPIE 1998, 77

${ }^{193}$ CAMPBELL 2020

${ }^{194}$ GORDON 1726, 52

195 HORSLEY 1732, 195

196 MACDONALD 1934, 374

197 WODROW 1843, 66

198 HORSLEY 1732, 163

199 KEPPIE 1998, 77
} 


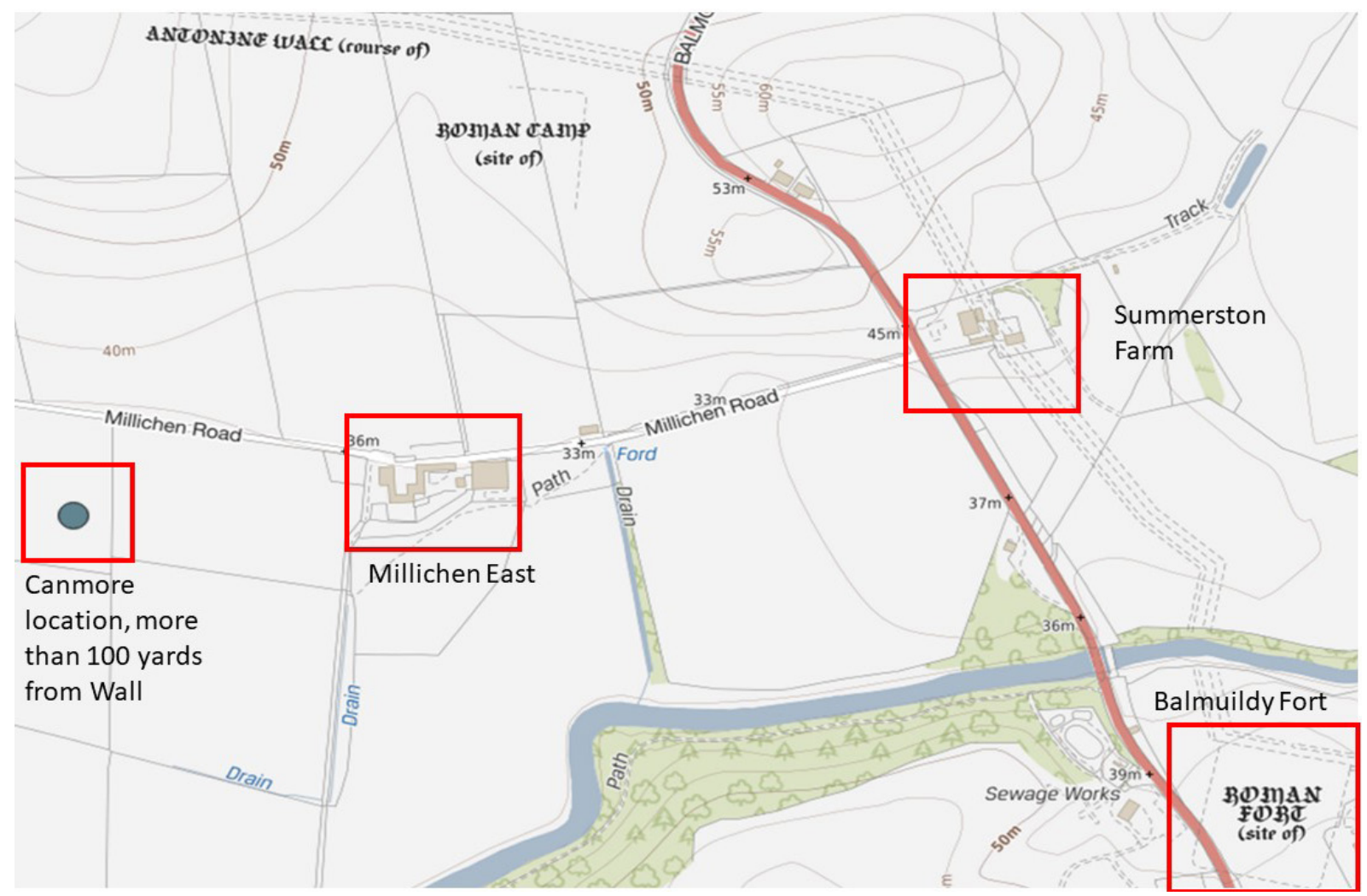

Fig. 11. Map plotting nos. 6 and 7 in relation to Summerston Farm and Millichen East ${ }^{200}$

\section{East Millichen, near Balmuildy (Glasgow Museums Number A.1942.18.01, RIB 2194)}

IMP CAES T AELIO HADRI ANTONINO AVG PIO P P VEXILLA LEG VI VIC P F PER M P III DCLXVIS (For the Emperor Caesar Titus Aelius Hadrianus Antoninus Augustus Pius, Father of his Country, the Sixth Victorious, Loyal and Faithful Legion built this over a distance of 3666 1/2)

Carved from buff sandstone, this Distance Stone was discovered in 1803 and is held in the collections of Glasgow Museums. It is poorly preserved due to exposure and resembles no. 8 in format with plain central panel containing inscribed text framed with plain single borders at each side and triple-stepped borders at the top and bottom. The inscription panel is flanked with plain peltae terminating with griffin heads and central rosettes. It contains the, by now familiar, distance of $36661 / 2$.

This Distance Stone was recovered from digging a deep drain at Low Millochan farm c. 100 yards from the Wall ${ }^{201}$ It is recorded as having been in the possession of a Glasgow schoolmaster, James Reekie, then passing to a relative on his death - a weaver from Calton who used the stone as a footrest before being acquired by James Ewing of Levenside who built it into his mansion at Queen Street in Glasgow ${ }^{202}$. Here, Macdonald's selectivity in sources is apparent, and significant. In the first edition of his The Roman Wall in Scotland ${ }^{203}$ he concludes "that it was lying so far south of the Rampart may be due either to its having been carried or to its having originally stood on the line of the Military Way". This last comment does not make it into his second edition ${ }^{204}$ and has not been picked up on since. He proceeds to conclude it was originally placed next to no. 6 based on the distances inscribed. It is plausible to posit that these two Distance Stones were once closely positioned without reverting to the complex series of suppositions that Macdonald imposes in order to fit into a measurement sequence that has already been established to be improbable on the basis that absence of evidence is not evidence for absence ${ }^{205}$. Like no. 6 , it was potentially located just to the south of the Wall in the vicinity of the Roman camp c. NGR NS 57427245.

\section{Castlehill (Hunterian Museum Number GLAHM.F.6, RIB 2196)}

IMP CAESAR T AELIO HADRIANO ANTONINO AVG PIO P P VEXILLATIO LEG VI VICTR P F PER MP III DCLXVIS (For the Emperor Caesar Titus Aelius Hadrianus Antoninus Augustus Pius, Father of his Country, a detachment of the Sixth Victorious, Loyal and Faithful Legion built this over a distance of 3666 1/2)

Carved from grey sandstone, this example was first recorded in 1696 and donated to the University in 1720. Decorative details are similar to no. 7, though the peltae here are more elaborately decorated in griffin-like plumage with rosettes at the terminals and centre. This inscription too refers to the oddly specific $3666 \frac{1}{2}$ units of measure and thought to be a partner to

\footnotetext{
200 CC CANMORE at $100 \mathrm{~m}$

201 STUART 1852, 315

202 STUART 1852, 315

${ }^{203}$ MACDONALD 1911, 299

204 MACDONALD 1934

205 SAGAN 1997, 213
} 
no. 7 marking the eastern stretch of the construction work ${ }^{206}$.

Contradictory accounts of the find location have been ascribed to this Distance Stone, with Gordon ${ }^{207}$ assigning it to New Kilpatrick built into the wall of a cottage at or near Castlehill while the Monumenta Romani Imperii ${ }^{208}$ and Anderson ${ }^{209}$ place it at Summerston. Macdonald supports the proposal for an original findspot at Castlehill, again, to fit his schematic for the Wall's construction based upon Bates ${ }^{210}$ proposals for paces recorded on nos. 1-8. This is hinged upon the yet more complex supposed inclusion of both paces and feet on no. 4 along with a sequence of elaborate calculations, that he concedes could be misleading, in order to "satisfy all the conditions"211 for its placement at Castlehill.

Here, we reach the crux of Macdonald's ${ }^{212}$ selective acceptance of accounts from his predecessors combined with Bates's theory for altered meanings ascribed to the units of measure contained in the inscription. He disregards proposals of a findspot at Summerston Farm near Balmuildy, preferring a source at Castlehill as it was reportedly built into a 'dike house' on the wall near Castlehill. Macdonald's proposal for this stone to derive from Castlehill as a pair to another, as yet undiscovered, example at the other end of a sector of Wall on the east which he hypothesises must have been placed close to no. 4 at Eastermains can only be reached through acrobatic arithmetic. Alternatively, this stone could indeed have originated from close to Summerston farm, near Balmuildy, where the artisan who created all four of these inscriptions measuring $36661 / 2$ may have been based. Perhaps from there they awaited transportation to their allocated place along a structure, most likely the Military Way as posited for nos 6 and 7. Keppie's ${ }^{213}$ proposed findspot at NGR NS 524728 would place it north of the Wall which contradicts his reference to it from south of the Wall so an alternative location c. NGR NS 57427245 at Summerston based upon the earlier accounts which may be more reliable sources.

This would leave the other three recovered from the Bearsden vicinity (nos. 9-11) all dedicated by a vexillation of the $20^{\text {th }}$ Legion and all recording a distance 3000 feet. If we tentatively place no. 2 (of unknown provenance) at Castlehill this would lead to a pairing of all the known Distance Stones dedicated by a detachment of the $20^{\text {th }}$ Legion (nos 2 \& $9 ; 10$ \& $11 ; 16$ $\& 17$ ) with only no. 4 devoid of a discovered partner, though that is the only example dedicated by the $20^{\text {th }}$ Legion as opposed to a detachment thereof. This is, of course, a controversial hypothesis since no. 2 records a distance of 'MIL P III', whilst no. 9 records 'P P III' and marks a change in the recording methodology on all Distance Stones hereafter westward.

\section{Castlehill (Hunterian Museum Number GLAHM.F.7, RIB 2197)}

IMP C T AELIO HADRIANO ANTONINO AVG PIO P P VEX LEG XX V(V) [F] P P III

(For the Emperor Caesar Titus Aelius Hadrianus Antoninus Augustus Pius, Father of his Country, a detachment of the Twentieth Valerian and Victorious Legion built this over a distance of 3000)

Carved from buff sandstone this Distance Stone was discovered in 1847 through ploughing which resulted in damage. It was acquired by John Buchanan shortly after discovery and thereafter donated to the Hunterian Museum in $1871^{214}$. This is a relatively plain panel inscription set within a cable/rope inner moulding and plain outer mould. A boar, Legionary symbol of the $20^{\text {th }}$, is carved in relief running to the left in the centre below the inscription and a single dovetail cramphole is carved into the top.

The findspot for this Distance Stone is recorded by Buchanan ${ }^{215}$ as being 3 foot beneath the surface where it was discovered by a ploughman on its side on the southern slope of Hutcheson Hill which he assumes indicates it was deliberately thrown into a pit then covered up. This follows Stuart's ${ }^{216}$ proposal that it was originally built into a structure in the fort before being carried down the hill by departing troops. There is a discrepancy in its placement on historical Ordnance Survey maps as well as a hand-drawn map that appeared in Macdonald's first edition ${ }^{217}$, see Fig. 12, placing the stone on the southern berm of the Wall c. 200 metres west of the fort despite Buchanan's statement that it was found 'within a few yards south from the fort $^{\text {'218. }}$. Keppie ${ }^{219}$ suggests this Distance Stone was located close to no. 8 and marks the eastern end of wall sector marked by nos 10 and 11 . Macdonald ${ }^{220}$ also suggests its placement on the Ordnance Survey maps is inaccurate, though he prefers a findspot further up the Castlehill to accommodate his proposal for the pairing of nos 9 and 10. Taking the information from its contemporaneous source, this Distance Stone should perhaps more accurately be assigned a findspot of c. NGR NS 52467258 as opposed to Canmore's placement at NGR NS 52297267 which places it north of the Wall or Keppie's suggestion of NGR NS 522727 which locates it north of the Wall and east of the fort.

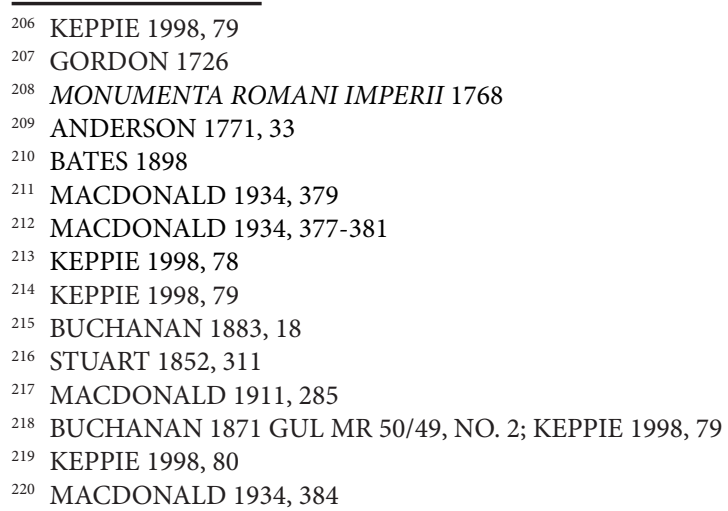




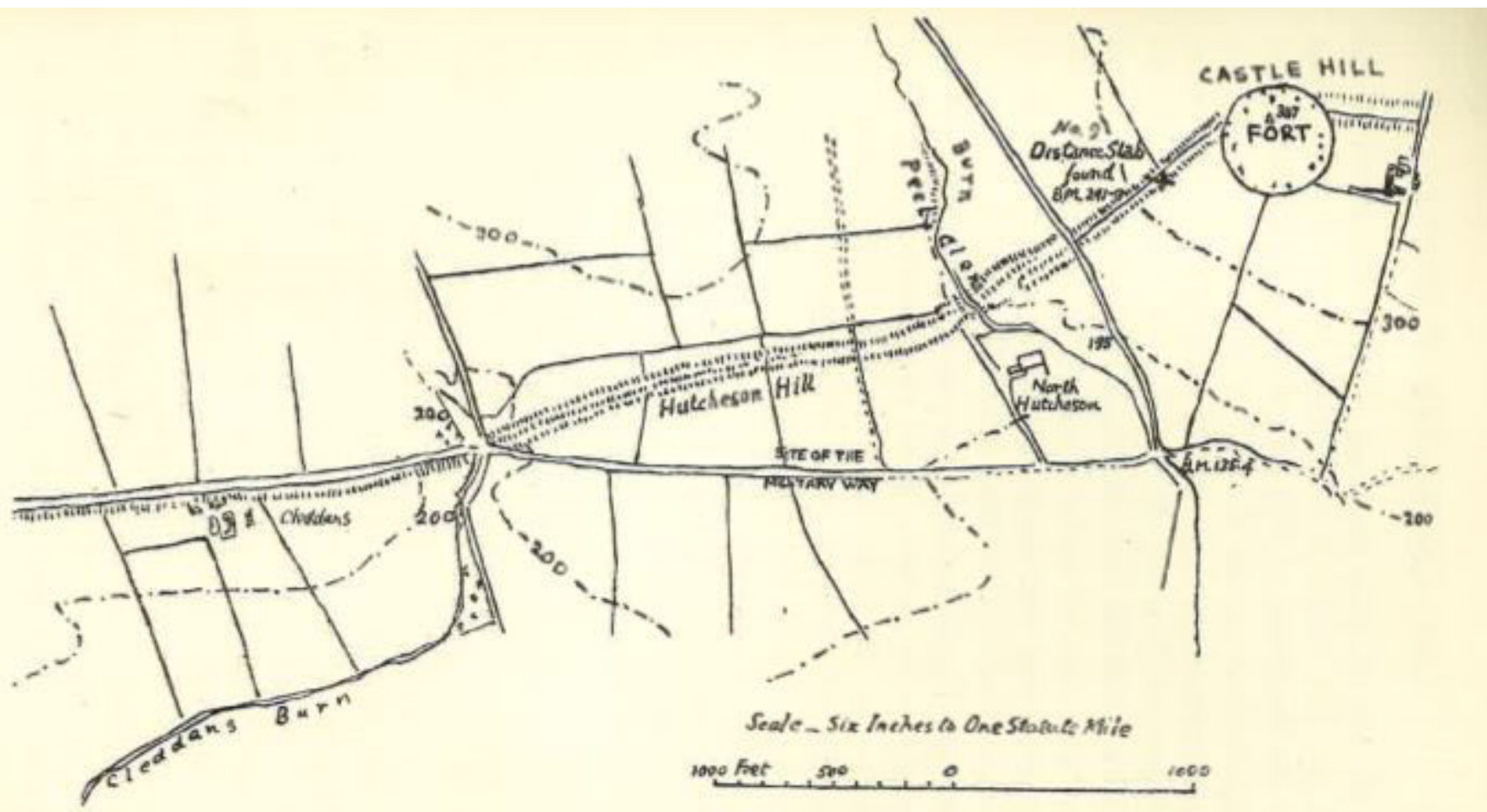

Fig. 12. hand-drawn map of Castlehill fort and placement of no. 9 Distance Stone ${ }^{221}$

\section{Hutcheson Hill (Hunterian Museum Number GLAHM.F.8, RIB 2198)}

IMP C T AEL HADRIANO ANTONINO AVG PIO P P VEX LEG XX VV FEC P P III

(For the Emperor Caesar Titus Aelius Hadrianus Antoninus Augustus Pius, Father of his Country, a detachment of the Twentieth Valerian and Victorious Legion built this over a distance of 3000)

Probably carved from yellowish-buff sandstone, this Distance Stone was discovered by a farmer digging trenches near the southern slope of Hutcheson Hill in 1865. Attempts were made to sell it to both the University of Glasgow and Hunterian Museum before its acquisition by Professor J H McChesney, the US Consul at Newcastle who had it shipped to Chicago where it perished in the Great Chicago Fire ${ }^{22}$. A plaster cast taken by the Antiquarian Society of Newcastle survives in the Hunterian after being donated by the Glasgow Archaeological Society sometime prior to 1879. Triple beaded mouldings frame a central panel with inscribed text flanked by ansae containing naked cupids carrying sickles and grapes. Three crampholes are recorded and indications of a fourth ${ }^{223}$.

The context of discovery is recorded as west of the Peel Glen in the southern slope of Hutcheson Hill south of the Wall where it was recovered face-down during trenching for drainage c. 3 foot below the surface ${ }^{224}$. Macdonald calculates that nos 9 and 10 were paired and mark opposite sectors of work on the Wall due their recording of 3000 feet which roughly corresponds with the measured distances between them ${ }^{225}$. Keppie's proposed placement c. NGR NS 516723 appears relatively accurate from the descriptive accounts.

\section{Hutcheson Hill (Hunterian Museum Number GLAHM.F.1969.22, RIB 3507)}

\section{IMP C T AE HADRIANO ANTONINO AVG PIO P P VEX LEG XX VV FEC PP III}

(For the Emperor Caesar Titus Aelius Hadrianus Antoninus Augustus Pius, Father of his Country, a detachment of the Twentieth Valerian and Victorious Legion built this over a distance of 3000)

Carved from yellowish-buff sandstone, this is an exceptionally well-articulated sculpture that depicts architectural features, including an archway in the centre with triangular pediments on the side atop Corinthian pillars. Under the central archway a female figure, thought to be a representation of Britannia rather than Victory who would normally be depicted with wings, holds a sacrificial dish in her left hand and presents a small laurel wreath to the eagle atop the legionary standard (aquila) held by an aquilifer ${ }^{226}$. They are flanked on either side by kneeling and bound captives looking on with inscribed roundels or shields behind them. The left captive is clean-shaven and naked like those on nos 1 and 6 , whilst the groin of the bearded captive on the right is covered by what appears to be a loincloth-like garment. In a central panel on the bottom the legionary boar charges to the right flanked by peltae.

\footnotetext{
${ }^{221}$ after MACDONALD 1911, 285

${ }^{222}$ KEPPIE 1998, 80

${ }^{223}$ BUCHANAN 1883, 14-17

224 BUCHANAN 1883, 14-17

${ }^{225}$ MACDONALD 1934, 384

226 KEPPIE 1998, 81
} 
This is the first Distance Stone to have been discovered in more than a century and was found in 1969 between Castlehill and Duntocher forts at Cleddans farm during ploughing c. $3 \mathrm{~m}$ south of the Wall in what the ploughman considered to be a shallow pit at NGR 51547234227. It was donated to the Hunterian Museum some months later. Like other examples, it has dovetail crampholes for securing this inscription to a supporting frame. Its recovery from the same field as no. 10 suggests these two were originally placed together, though doubt has been cast on whether the distance inscribed fits into Macdonald's schematic $^{228}$. The authors suggest nos 9,10 and 11 must all refer to the same sector of work and may have been placed on the north and south of the Wall. Perhaps more likely, it is here suggested they were located on either side of the Military Way.

\section{Braidfield Farm, Duntocher (Hunterian Museum Number GLAHM.F.9, RIB 2200)}

IMP C T AELIO HADRIANO ANTONINO AVG P P VEX LEG VI VICTRICS P F OPVS VALLI P (X)(X)(X) CCXL F (flag: VIRT AVG)

(For the Emperor Caesar Titus Aelius Hadrianus Antoninus Augustus, Father of his Country, a detachment of the Sixth Victorious, Loyal and Faithful Legion built the work of the wall over a distance of 30,240)

(On flag: Virtus Augusta - Valour of the Emperor)

Carved from yellowish-buff sandstone, this Distance Stone is also exquisitely sculpted and depicts two winged Victories with right feet resting on globes holding up an inscribed panel framed by peltae and flanked on the left by a bearded Mars in full panoply and Valour in Amazoninian attire and holding a on the right holding a flag inscribed with VIRT AVG ${ }^{229}$. It was discovered in 1812 and shortly thereafter donated to the Hunterian Museum.

There are some significant similarities between nos 12 and 15 , both commemorating the $6^{\text {th }}$ Legion, that differ markedly from all other Antonine Wall Distance Stones. They are, for example, the only examples dedicated to the Emperor that do not include his title of $\mathrm{Pio}^{230}$. They are also the only examples that make explicit reference to construction of the Wall (OPVS VALLI) and both are the only two to include symbols ' $\mathrm{X}$ )' thought to indicate thousands as a variant of ' $\mathrm{M}$ '231. However, more likely this practice of framing an $\mathrm{X}$ in brackets is an abbreviated way to define $10,000^{232}$ meaning that instead of the traditional translation of this distance as 3240 it should, in fact, more accurately read $\mathbf{3 0 , 2 4 0}$ feet.

There is sparse information recorded as to the find context for this inscription, save for it being found in 1812 on Braidfield Farm c. half a mile south-east of Duntocher ${ }^{233}$. Macdonald ${ }^{234}$ places this on the third field to the left of the road westward of Cleddans Farm, probably c. NGR NS 5033 7221. This differs slightly from Canmore's recorded spot c. NGR NS 507722 and Keppie's ${ }^{235}$ proposed spot immediately beside Braidfield Farm at NGR NS 501 721. In his first edition Macdonald ${ }^{236}$ notes this is the stone referred to on historic Ordnance Survey maps close to the Roman bridge just north of Duntocher Burn, though he has altered this in the second edition to refer instead to no. $13^{237}$.

\section{3 - Unknown provenance, possibly near Duntocher (Hunterian Museum Number GLAHM.F.10, RIB 2203)} LEG II AVG F P IIII CXL

(The Second Augustan Legion built this over a distance of 4140)

Carved from buff sandstone, this Distance Stone was donated to the Hunterian Museum between 1826 and 1845 and the circumstances of its discovery are unrecorded though Stuart ${ }^{238}$ suggested it could have belonged to either Duntocher or another fort. Stylistically it is almost identical to no. 14 with inscribed text framed in a central panel, here with acanthus leaf patterns ${ }^{239}$, flanked by peltae with griffin-head terminals and rosettes in each corner. On the top a Capricorn with twisted tail swims to the left and on the bottom a winged Pegasus also gallops left. This is one of only two examples that are devoid of a dedication to the Emperor (see also no. 4), though close inspection of no. 14 strongly suggests the dedication is a later addition to the original sculpture. There are two dovetail crampholes on the top.

The findspot for this Distance Stone has not been ascertained with any degree of certainty and is based on conjecture, first by Stuart ${ }^{240}$ who does state it could easily have been derived from another fort but has been assigned to Duntocher based upon the stylistic similarities with no. 14. It is thought to record a distance westward from Braidfield ${ }^{241}$, despite not finding any parallel with the example from Braidfield (no. 12) either stylistically, in measured distance or in the dedicating legion (no. 12 by Legio IV and no. 13 by Legio II). Keppie ${ }^{242}$ assigns it an NGR findspot of NS 595 728, but that would place it significantly north of the wall near Wilderness Plantation and west of Cawder House. More likely it is correctly placed by Canmore c. NGR

\footnotetext{
227 STEER/CORMACK 1969, 122

228 STEER/CORMACK 1969, 124

229 KEPPIE 1998, 83-4

${ }^{230}$ STUART 1852, 298

231 KEPPIE 1998, 84

232 BRUUN/EDMONDSON 2014, 813

${ }^{233}$ STUART 1852, 297

234 MACDONALD 1934, 385

235 KEPPIE 1998, 83

236 MACDONALD 1911, 297

237 MACDONALD 1934, 386

238 STUART 1852, 298

239 KEPPIE 1979, 17; contra. KEPPIE 1998, 84

240 STUART 1852, 298

241 MACDONALD 1934, 386

${ }^{242}$ KEPPIE 1998, 84
} 
NS 49317279 near the Roman Bridge noted in the historic accounts ${ }^{243}$. It has been suggested this stone may find a partner with no. 15 by a detachment of the $6^{\text {th }}$ Legion since the distance here (4140) is thought to differ only by one foot to no. 15 which records 4141 which may be the result of an error by the inscriber ${ }^{244}$. However, see notes on nos 12 and 15 , it is here suggested that errors permeate traditional translation of no. 15 which should alternatively be read as 40,141 feet.

\section{4 - Carleith, Duntocher (Hunterian Museum Number GLAHM.F. 12, RIB 2204)}

\section{IMP ANTON AVG PIO P P LEG II AVG F P III CCLXXI}

(For the Emperor Antoninus Augustus Pius, Father of his Country, the Second Augustan Legion built this over a distance of 3271)

Carved from buff sandstone, this Distance Stone was incorporated above the gate at Cochno House, near Duntocher ${ }^{245}$ and has a small triangular cramphole in the top centre ${ }^{246}$. It was donated to the University of Glasgow between $1732-1759$ by the owner of Cochno House, James Hamilton of Barns. Stylistically, this is a very close copy of no. 13, but the border of the inscribed panel is cabled and it includes a dedication to the Emperor Antoninus Pius, though its placement squeezed into gaps between the Capricorn in the top section has clearly not been planned into the original sculpting ${ }^{247}$. Additional slight variations appear with the Capricorn's tail which in this sculpture is straightened and the rosettes are more complex in structure. Critically, the distances are not duplicated so they evidently do not form a pair marking either end of a completed stretch of construction work, though no. 14 is thought to mark a sector between Duntocher and Carleith ${ }^{248}$. Macdonald ${ }^{249}$ posits that it records the distance between nos 13 and 14 .

The original findspot for this Distance Stone is unrecorded, though it has been reasonably assumed to have come from close to Duntocher given the assertion by Stukeley ${ }^{250}$ that it was found at Carleith combined with its placement at Cochno House which is the immediate vicinity of the fort ${ }^{251}$. Keppie ${ }^{252}$ has erroneously assigned a findspot at NGR NS 481731 which would place it north of the wall close to Dalnottar Cemetery. More likely it could have originally been located closer to the spot assigned on Canmore c. NGR NS 482 729, though in the circumstances that is conjecture.

\section{5 - Old Kilpatrick, Dalnottar Burn? (Hunterian Museum Number GLAHM.F.13, RIB 2205)}

IMP C T AELIO HADRIANO ANTONINO AVG P P VEX LEG VI VIC P F OPVS VALLI P $(X)(X)(X)(X)$ CXLI

(For the Emperor Caesar Titus Aelius Hadrianus Antoninus Augustus Pius, Father of his Country, a detachment of the Sixth Victorius, Loyal and Faithful Legion built the work of the wall over a distance of 40,141)

Carved from greyish buff sandstone, this inscription is set within a plain double moulding with guidelines above and below letters faintly visible as well as a seventh line that was ultimately not inscribed ${ }^{253}$. It has a small dovetail cramphole in the top. Although not stylistically similar, the inscription on this example bears striking similarities with no. 12, including making explicit reference to the construction of the Wall through the term 'OPUS VALLI', omission of 'PIO' in the Emperor's title, a feature that is unique to both and ascribed by Macdonald ${ }^{254}$ as accidental rather than ignorance, and both contain (X) symbols for thousand. However, like no. 12, this is probably an abbreviated way to define $10,000^{255}$ meaning that instead of the traditional translation of this distance as 4141 it should, in fact, more accurately read $\underline{\mathbf{4 0}, \mathbf{1 4 1} \text { feet. }}$

Its context of discovery is not clear, the closest findspot recorded as it being ploughed up in the Parish of Kilpatrick in Lennox "where the wall ended" 256 between Glasgow and Dumbarton Castle on the lands of William Hamilton of Orbiston. It was then briefly retained at Hamilton's country home at Erskine House, south of the River Clyde, before he donated it to the University of Glasgow in $1695^{257}$ along with no. $16^{258}$. The historical sources make no mention of Dalnottar, but Stuart's ${ }^{259}$ statement that nos 15 and 16 were recovered from the Chapel-hill (Old Kilpatrick fort) matches the earlier accounts of its recovery from the Wall terminus at NGR NS 4600 7315. Despite this, and Macdonald's ${ }^{260}$ earlier acceptance of this findspot, it has been traditionally ascribed to Dalnottar Burn marking the Wall sector from there to Carleith (c. NGR NS 471731 on Canmore) following on from no. $15^{261}$ to fit into Macdonald's proposed schematic.

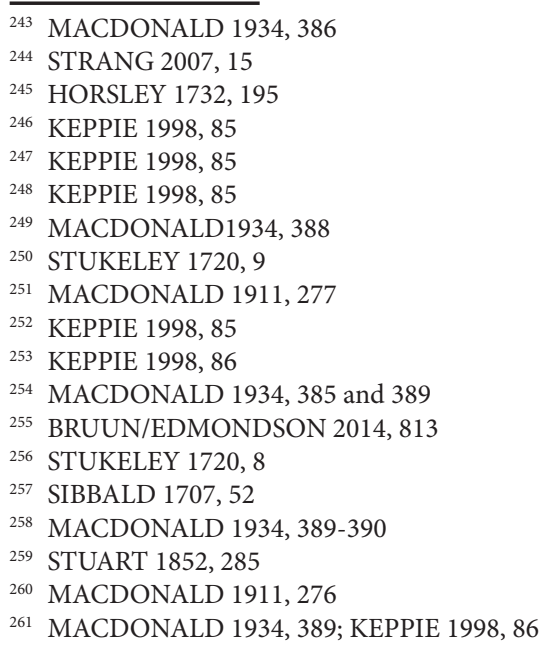




\section{6 - Old Kilpatrick, Dalnottar Burn? (Hunterian Museum Number GLAHM.F.14, RIB 2206)}

[I]MP C T AE [H]ADRIANO [A]NTONINO [AV]G PIO P P [VEX L]EG XX VV [PP IIII C]DXI

(For the Emperor Caesar Titus Aelius Hadrianus Antoninus Augustus Pius, Father of his Country, a detachment of the Twentieth Valerian and Victorious Legion built this over a distance of 4411)

Carved from yellowish-buff sandstone, this inscription was donated to the University of Glasgow by William Hamilton of Orbiston, owner of Erskine House, in 1695 along with no. 15. It contains a central panel inscription bounded by triple mouldings and an ansate on the right which was probably duplicated on the left which is now missing. Inside the ansate is a naked and winged cupid carrying a bunch of grapes and sickle ${ }^{262}$. There is a small triangular cramphole in the top right of centre which was possibly matched by another on the left missing segment. It mirrors no. 10 from Hutcheson Hill in style, dimension and iconography and may also at one time have depicted a boar galloping toward a tree at the bottom as the emblem of the $20^{\text {th }}$ Legion, dedicators of both stones.

As with no. 15, the findspot for this Distance Stone is not recorded, though Keppie ${ }^{263}$ does indicate Old Kilpatrick (NGR NS 4600 7315) as a potential candidate for its discovery as the eastern partner to no. 17 which duplicates the recorded distance on this inscription. It could alternatively have been placed alongside no. 17 with both facing opposite directions on either side of the Military Way.

\section{7 - Old Kilpatrick, Ferrydyke? (Hunterian Museum Number GLAHM.F.15, RIB 2208)}

\section{IMP C T AE HADRIANO ANTONNO AVG PIO P P VEX LEG XX V V FEC P P IIII CDXI}

(For the Emperor Caesar Titus Aelius Hadrianus Antoninus Augustus Pius, Father of his Country, a detachment of the Twentieth Valiant and Victorious Legion built this over a distance of 4411)

Carved from buff sandstone, this ornately decorated Distance Stone was donated to the University of Glasgow before 1684 on the death of the Third Marquis of Montrose ${ }^{264}$. As the Marquesses did not own the land on which Old Kilpatrick sits it may have come into his possession from a third party and is recorded as having been located in Mugdock House prior its destruction in the wars of $1640^{265}$ and before the death of the donor ${ }^{266}$. The inscribed text mirrors that of no. 16 , both dedicated to the $20^{\text {th }}$ Legion and marking a distance of 4411 . The iconography depicts a reclining winged Victory beneath a pediment atop fluted pilasters with Corinthian capitals. The goddess is holding an upright palm frond in her left hand and a large laurel wreath in her right which has been used as a panel to hold some of the inscribed text. Her left elbow rests on a globe with criss-crossed bands and below her an elongated ansate panel has the legionary symbol of a boar facing leftward with the measured distances on either side of it. There is a dovetail ${ }^{267}$ cramphole in the top. Since it matches the distance on no. 16 , it is thought to record the completion of a sector between Dalnotter Burn and Old Kilpatrick fort ${ }^{268}$.

The findspot for this Distance Stone is not recorded, Sibbald ${ }^{269}$ notes only that it came from the Wall and Gordon ${ }^{270}$ assigns it with other carved stones from Old Kilpatrick while Maitland ${ }^{271}$ states it derives from Ferrydyke, on the River Clyde close to the fort. Its place of discovery cannot, therefore, be assigned with any more accuracy than the environs of Old Kilpatrick fort, though Keppie ${ }^{272}$ likens the reclined position of Victory to the pose normally adopted by river gods which may refer to its placement close to the River Clyde. If the reference to Ferrydyke is reasonably accurate at c. NGR NS 4590273000 , this stone could well mark the western terminus of the Wall or Military Way which could explain its exquisite sculptural detail and stylistic composition mirroring sculptures of river gods.

\section{8 - Duntocher, Cochno Estate (Hunterian Museum Number GLAHM.F.11, RIB 2199)}

IMP C T AE HADRIANO ANTONINO AVG PIO P P VEX LEG XX VV FEC P

(For the Emperor Caesar Titus Aelius Hadrianus Antoninus Augustus Pius, Father of his Country, a detachment of the Twentieth Valiant and Victorious Legion built this over a distance of ...)

Carved from buff sandstone, this inscription is set against a plain panelled background with cabled border and stylistically very similar to no. 9, though on this example the legionary boar faces to the right and this is a five-sided shape as opposed to rectangular with a dovetail cramphole in the gable angle ${ }^{273}$. Although previously dismissed as a 'waster'274, this is very clearly an unfinished inscription, one of only two examples devoid of measured distance. Given the very small dimensions of the area to the right of the boar where measurement would logically have been inscribed, a very short distance of 'III' is likely to have been intended for inclusion here, as with no. 9.

The original findspot for this Distance Stone is unrecorded, though it was assumed to derive from Duntocher near the

\footnotetext{
262 KEPPIE 1998, 87

263 KEPPIE 1998, 87

264 STUKELEY 1720, 10

${ }^{265}$ KEPPIE 1998, 68 and 88

266 GORDON 1726, 50

${ }^{267}$ KEPPIE 1998, 88

268 KEPPIE 1998, 88

269 SIBBALD 1707, 207

${ }^{270}$ GORDON 1726, 50

271 MAITLAND 1757, 182

272 KEPPIE 1998, 88

273 KEPPIE 1998, 82

${ }^{274}$ MACDONALD 1934, 387
} 
Cochno Estate purely because of its donation to the University of Glasgow in October 1699 by the owner of the estate, Claud Hamilton of Barns ${ }^{275}$, before his descendent, James Hamilton of Barns, donated no. 14. In his second edition Macdonald ${ }^{276}$ dismisses it as a 'waster', though he does question its provenance from Cochno purely on the basis that the $20^{\text {th }}$ Legion "was busy elsewhere".

Following Maxwell's ${ }^{277}$ hypothesis, Keppie ${ }^{278}$ agrees this must refer to one of the work-sectors completed by the $20^{\text {th }}$ Legion west of Castlehill. However, given its duplication of no. 9 except for the omission of completed distance, the clear evidence of some stones moving between owners of different estates (e.g. nos 2 and 17), the dedication by detachments of the $20^{\text {th }}$ and the duplicate distances of 3000 units of measure, it is here proposed that this inscription may have originally been located at Castlehill alongside nos 9, 10, 11, and possibly 2. This may indicate four stones commemorating each work sector with two placed at either end or, taken a step further, it is possible that we may have identified a second artisan's workshop at Castlehill c. NGR NS 5246 7258, as at Balmuildy, which may explain the absence of measurement inscribed onto this incomplete example. It is incorrectly placed at NGR NS 4972 on Canmore which is a distance away from Duntocher fort.

\section{9 - Arniebog, Cumbernauld, near Westerwood (Hunterian Museum Number GLAHM.F.16)}

No inscription (broken object)

Carved from yellow sandstone, this is a fragment from the left side of a large sculpted stone which could be a commemorative tablet. However, it is assumed to have been a Distance Stone due to its recovery from the vicinity of the Antonine Wall along with the sculpted detail of a naked captive resting on one knee with hands bound behind his back, as depicted on other examples such as nos 1, 6 and 11, and a bearded Triton above with twisted tail holding an anchor in the crook of his right arm ${ }^{279}$. The dimensions allude to an original rectangular shape and an internal panel with cabled border differs from the other examples as it takes the shape of diamond or hexagon ${ }^{280}$ that is reminiscent of the screens fronting the Principia at Vindolanda ${ }^{281}$. Although the decorative technique of triple borders have been likened to those of the $20^{\text {th }}$ Legion on nos 10,11 and $16^{282}$, comparisons are perhaps more legitimately made with the kneeling bound captives on examples dedicated by the $2^{\text {nd }}$ Legion, nos 1 and 6 , and the $20^{\text {th }}$ Legion's no. 11, particularly the latter. This sculpture was acquired by John Buchanan and donated to the University of Glasgow along with other inscribed stones in $1872^{283}$. There is one dovetail cramphole on the left side.

This sculpture was discovered through ploughing by the family of farmer, William Chalmers, from a field bounded on the north by 'Grim's Sheugh' (the Wall) around 34 feet from the mural barrier, between Westerwood fort and Castlecary fort which lay c. 1 mile to the east ${ }^{284}$. Keppie ${ }^{285}$ suggests a findspot c. 450 m further east of Arniebog farm based on the descriptive account at Hag Knowe. This would place the stone at NGR NS $770777^{286}$ on the Military Way (not at c. NS 766775 as noted on Canmore).

\section{0 - Old Kilpatrick, Ferrydyke (lost)}

Unknown inscription (missing object)

An inscription thought to be a Distance Stone was at one time built into the threshold of a house at Ferrydyke c. NGR NS 4590273000 where it was recorded as being carved with a curiously sculpted $8.75 \mathrm{~cm}$ border containing an inscription that was so worn by walking over that it was unintelligible ${ }^{287}$. Keppie ${ }^{288}$ suggests the description matches that of no. 9 dedicated by the $20^{\text {th }}$ Legion who constructed this sector of the frontier as confirmed by the other Distance Stones in the vicinity. It is now lost.

\section{1 - Bar Hill (CIL vii 1110a, RIB 2312? - lost)}

\section{IMP CAES T AELIO ADRIA ANTINO AVG P O P P ...VEXLL}

(For the Emperor Caesar [Titus] Aelius Hadrianus Antoninus Augustus Pius, Father of his Country, a detachment of)

Macdonald ${ }^{289}$ makes a passing note to an 'imperfect inscription' that he considers to have been a Distance Stone based on the inscribed text recorded in CIL vii (1110a). Although Macdonald states it must have originated from Croy Hill or Bar Hill, the CIL note records it quite clearly from Bar Hill 'in pariete horti domini de Kilseith', (Kilsyth) at c. NGR NS 707 759, not at Croy Hill as noted on Canmore (NGR NS 733 765). This may refer to RIB 2312 which could be a column-shaft milestone rather than a Distance Stone ${ }^{290}$.

\footnotetext{
275 GORDON 1726, 61; MACDONALD 1911, 279; HAMILTON 1933, 121; KEPPIE 1998, 83

276 MACDONALD 1934, 387

277 MAXWELL 1974

278 KEPPIE 1998, 82

279 KEPPIE 199, 89

280 KEPPIE 1979, 20

281 KEPPIE 1998, 90

${ }^{282}$ KEPPIE 1988, 89

283 KEPPIE 1988, 89

284 BUCHANAN 1872, 473

${ }^{285}$ KEPPIE 1974, 154

286 KEPPIE 1998, 89

287 MAITLAND 1757, 183

288 KEPPIE 1979, 20

${ }^{289}$ MACDONALD 1934, 392

${ }^{290}$ W HANSON, pers. comm.
} 